Piotr Fiedorczyk (Białystok), Adam Lityński (Sosnowiec), Anna Stawarska-Rippel (Katowice)

\title{
Wojny XX wieku i ich skutki dla ustrojów państwowych i prawa
}

\section{UPADEK IMPERIÓW}

Wiek XIX, a zwłaszcza jego druga połowa, niósł ze sobą nowe wielkie zjawiska: nacjonalizm i socjalizm. Postępowało kształtowanie się nowoczesnej świadomości narodowej tam, gdzie jej jeszcze nie było, do pojawienia się nacjonalizmów włącznie. Wśród narodów żyjących pod obcym panowaniem nacjonalizm pełnił z reguły funkcję obronną przed wynarodowieniem. W wyniku pojawienia się kwestii robotniczej narodziły się społecznie wrażliwe kierunki socjalne (m.in. w prawie cywilnym; narodziny prawa pracy; papieska encyklika Rerum novarum 1891), aż do koncepcji tworzenia sprawiedliwego porządku w świecie, co przybrało postać ideologii socjalistycznej oraz komunistycznej (Manifest komunistyczny 1848). Odrodzenie narodowe, świadomość narodowa, nacjonalizm, rasizm, prądy religijne, socjalne, przeplatały się ze sobą, wspomagając się wzajemnie albo przeciwnie - pozostając w opozycji.

Upadek Imperium Rosyjskiego w XX w. miał swój początek w wojnie rosyjsko-japońskiej 1904-1905. Wojna rosyjsko-japońska to wydarzenie ważniejsze niż się nam - z perspektywy nadwiślańskiej - niekiedy wydaje. Była to bowiem klęska poniesiona $\mathrm{z}$ ręki dopiero wschodzącego imperium azjatyckiego. Dla ludów żyjących gdzieś na kresach Imperium Rosyjskiego był to sygnał, że imperium nie jest niepokonane, a nawet że pokonać je może daleki i nieznany kraj z Azji. Wewnątrz Imperium Rosyjskiego klęska w wojnie z Japonią - jak wiadomo - skutkowała rewolucją, pierwszą wielką rewolucją rosyjską, i to rewolucją ludową. To nie elitarne powstanie dekabrystów. To pierwsze takie wydarzenie w Imperium Rosyjskim, które nim zatrzęsło, chociaż go nie zburzyło. Po opanowaniu sytuacji reżim przejdzie do reakcyjnych represji. Jednak jeszcze nigdy 
carat nie doznał takich wstrząsów społecznych i nigdy w dziejach Rosji nie był zmuszony do reform ustrojowo-politycznych. Ponadto wydarzenia rewolucyjne 1905-1907 przyniosły dwa niespotykane wcześniej zjawiska: ludowe rady oraz bunty żołnierzy, w tym marynarzy. I jedno, i drugie odżyje w dziesięć lat później, a od razu należy powiedzieć, że bez nieposłuszeństwa żołnierskiego nie byłoby w Rosji zwycięstwa rewolucji ani w lutym, ani w październiku, i historia świata potoczyłaby się inaczej.

Zachodnie mocarstwa od dawna zdobywały zamorskie kolonie. Wschodnie imperium również je od dawna zdobywało: najpierw Syberię, w XIX wieku Azję Centralną, zwaną też Środkową (Turkiestan, Buchara, a zamysły w Petersburgu poprzez Zakaukazie_oraz Morze Kaspijskie - szły w kierunku wyparcia Anglików z Afganistanu, z Indii, Tybetu oraz opanowania Persji). Tę niebezpieczną rywalizację mocarstw, tzw. „wielką grę” (the Great Game), zakończyła rosyjska klęska w wojnie japońskiej, jak też widmo rosnącego zagrożenia ze strony Niemiec, czyli zbliżającej się wojny, nazwanej później pierwszą światową, i ukształtowanie się trójporozumienia Wielkiej Brytanii, Francji i Rosji. W 1907 r. podpisane zostało porozumienie brytyjsko-rosyjskie dotyczące Tybetu, Afganistanu oraz Persji ${ }^{1}$, bez jakiegokolwiek udziału tych krajów. W Tybecie przywrócono stan poprzedni, Rosja uznała protektorat brytyjski nad Afganistanem, zaś co do Persji postanowiono, że podzielona ona zostaje na trzy strefy, a mianowicie strefę wpływów południową - brytyjską, strefę wpływów północną - rosyjską oraz neutralną strefę środkową, stanowiącą swoisty bufor.

Porażka Rosji na Dalekim Wschodzie (z Japonią) i wspomniane porozumienie z Wielką Brytanią skłonią imperium carów do skoncentrowania imperialnej uwagi na kierunku europejskim, na Bałkanach. Tam się kruszyło Imperium Osmańskie, a zwycięstwo Japonii dało impuls ruchowi młodotureckiemu. Już przed I wojną światową „niewierni” Europejczycy dokonali wstępnego rozbioru Turcji (utrata Bułgarii 1908, Libii 1912, Albanii 1912).

Kiedy rozpalała się wojna światowa, Rosja przystępowała do niej z planami przyłączenia do Imperium Rosyjskiego Konstantynopola i cieśnin czarnomorskich, tureckiej części Armenii, a w Europie - Galicji. Byłoby to realne², gdyby Rosja nie zawarła separatystycznego pokoju.

${ }^{1}$ Конвенция между Россией и Англией по делам Персии, Афганистана и Тибета 8 (31) aвгуста 1907 2. [Konwencija mieżdu Rosijej i Anglijej po diełam Persii, Afganistana i Tibeta 8(31) awgusta 1907 g.], online: http://www.hrono.ru/dokum/190_dok/19070818ru_gb.php [dostęp: 07.01.2018].

${ }^{2}$ Podyktowane Turkom na brytyjskim okręcie wojennym w Mudros (30.10.1918) warunki rozejmowe były nie tylko twarde, lecz wręcz druzgocące. Zwycięscy kapitaliści przystąpili do dzielenia łupów: dwa dni po zawarciu rozejmu z Niemcami (13.11.1918) wojska brytyjskie opanowały cieśniny czarnomorskie i wkroczyły do Stambułu; w kilka miesięcy później wojska greckie wylądowały w Izmirze (z zamiarem stworzenia drogą faktów dokonanych Wielkiej Grecji), zaś włoskie 
Rewolucję lutową 1917 r., która zmiotła panującą od trzystu lat dynastię Romanowów i była jednocześnie upadkiem Imperium Rosyjskiego, wywołała oczywiście wojna światowa, a ściślej: rosyjskie klęski w wojnie. A klęski rosyjskie na froncie europejskim były niewyobrażalne. Rewolucja lutowa 1917 r. zaskoczyła wszystkich, mimo że wewnętrzny ferment od dłuższego już czasu wyraźnie się nasilał. Zmiotła wszystko, co do tego czasu było w Rosji z urządzeń ustrojowych. $\mathrm{W}$ warunkach zagrożenia zamachem stanu, tak z lewicy, jak i prawicowym, Rząd Tymczasowy zdecydował się jednak na proklamowanie republiki dekretem rządowym (14/01.09.1917). Honorowa próba pozostania lojalnym wobec sojuszników w wojnie światowej przynosiła na europejskim froncie kolejne straszne klęski. Osiem miesięcy Rządu Tymczasowego to jedyny przed 1991 r. w dziejach Rosji okres wolności politycznej. Rosja „nie zawdzięczała jednak tej wolności jakiemukolwiek ładowi prawnemu, ale temu głównie, że żadna siła społeczna nie panowała nad sytuacją"”. Efektem był bolszewicki zamach stanu.

Najpóźniej w 1917 r. ani „biała”, ani „czerwona” Rosja absolutnie nie była już w stanie prowadzić wojny. Poniosła druzgocącą klęskę. Nie sposób nie docenić skutków separatystycznego traktatu brzeskiego państw centralnych z Rosją (03.03.1918), a drugoplanowo także z Ukrainą (09.02.1918). Miał on znaczenie nie tylko dla przebiegu działań na frontach, lecz przede wszystkim dla dalszych wydarzeń politycznych i w konsekwencji ustrojowych Europy Środkowo-Wschodniej. Wszak Rosja została pokonana i wojska niemieckie były pod Piotrogrodem. Niektóre z krajów między Rosją a Niemcami próbowały budować swoją państwowość w oparciu o Niemcy i w związku Rzeszą (Mitteleuropa).

Widoczne jest, że zwycięzcy w I wojnie światowej w rozmaity sposób zyskali w jej wyniku, natomiast rozpadły się aż cztery imperia, przy czym w co najmniej trzech z nich wybuchły rewolucje (Rosja, Rzesza Niemiecka, Imperium

w południowej Anatolii. Anglicy z Francuzami ścigali się w zajmowaniu południowych terenów byłego imperium: m.in. Iraku, Palestyny, Syrii, krajów arabskich. Zgodnie z wizją Wilsona miała powstać Wielka Armenia (miała otrzymać sześć prowincji byłej Turcji), miał także powstać autonomiczny, a w przyszłości prawdopodobnie niepodległy Kurdystan. Jak wiadomo, 10 sierpnia $1920 \mathrm{r}$. w Sèvres pod Paryżem przedłożono Turcji warunki traktatu pokojowego; przedstawiciele tureccy go sygnowali. Na jego mocy Turcja miała utracić trzy czwarte swojego dotychczasowego terytorium. Wielka Brytania otrzymywała jako terytoria mandatowe Arabię, Mezopotamię, Palestynę oraz Mosul; Francja mandaty nad Syrią oraz Cylicją; Grecja miała otrzymać Trację Wschodnią z Półwyspem Gallipoli oraz Smyrnę (Izmir), w której po pięciu latach miał odbyć się plebiscyt; Włochom miał przypaść ogromny obszar południowo-wschodniej Anatoli od Adalii (Antalya) do Konyi; na południu miał powstać Kurdystan cieszący się autonomią, a na wschodzie niepodległa Wielka Armenia, której ostateczne granice miały być poddane pod arbitraż prezydenta USA Wilsona. Cieśniny miały zostać zdemilitaryzowane i miała być zapewniona swobodna żegluga. Ponadto Turcja miała utrzymywać armię nie większą niż 50 tys. żołnierzy, miała wydać aliantom niemal całą flotę, zlikwidować fortyfikacje w cieśninach. Zbrodniarze Imperium Osmańskiego mieli zostać osądzeni.

3 L. Kołakowski, Główne nurty marksizmu. Powstanie, rozwój, rozkład, Londyn 1988, s. 746. 
Osmańskie, a tylko w pewnym stopniu rewolucja dotknęła imperium Habsburgów). Rozpad tych imperiów wywołany był we wszystkich przypadkach przegraną wojną światową, co oczywiście dotyczy także Rosji, dla której traktat brzeski (03.03.1918) był najbardziej upokarzającym traktatem pokojowym od setek lat. Trzy z czterech imperiów - Rosyjskie, Austro-Węgierskie i Osmańskie - jeszcze przed 11 listopada 1918 r. stanęły w obliczu drastycznego rozbioru każdego z tych krajów. Tylko w monarchii Habsburgów przebiegło to względnie spokojnie. Niemcy wstrząsane były komunistycznymi próbami przejęcia władzy i tylko sprawny oraz karny aparat administracyjny, zwłaszcza policja i wojsko, pozwolił zlikwidować te próby. W Rosji przeciwnie, zwłaszcza wojsko było w rozpadzie i zrewoltowane.

\section{PO 11 LISTOPADA 1918 R.: KONIEC WOJNY ŚWIATOWEJ?}

W istocie I wojna światowa wcale nie skończyła się 11 listopada 1918 r. Rosja - tak „biała”, jak i „czerwona” - oraz Turcja wznowiły wojnę po tym dniu. Już w 48 godzin po podpisaniu rozejmu zachodnich aliantów z Niemcami bolszewicy wypowiedzieli traktat brzeski i wkrótce ruszyli na zachód w imperialnym pochodzie. Pozostawione okresowo na terenach Ober-Ostu wojska niemieckie $\mathrm{w}$ istocie nie stanowiły wystarczającej bariery osłonowej - żołnierze niemieccy nie chcieli po zakończeniu wojny umierać za ochronę nie swojej ziemi. Wyjątek stanowiły jednostki wojskowe Niemców nadbałtyckich, którzy mieli koncepcję związku państwowego z państwem niemieckim. Najsłabsza nad Bałtykiem Litwa też bardzo długo widziała swoją przyszłość w silnym związku z Niemcami, wręcz $\mathrm{w}$ przyjęciu nieformalnego protektoratu niemieckiego. Imperialny marsz sowiecki, jak dobrze wiemy, miał nie tyle przywrócić dawne granice „białego” imperium, z dodatkiem jeszcze Galicji, co przede wszystkim dotrzeć do skomunizowanych Niemiec i rozpalić komunistyczną rewolucję europejską, a później światową. Estończycy, Łotysze i Finowie (ci zwłaszcza z niemiecką pomocą), a przede wszystkim najsilniejsi i najbardziej na zachód oddaleni Polacy wzięli udział w drugim akcie pierwszej wojny światowej - teraz z Rosją.

W najbardziej skomplikowane położenie uwikłała się Ukraina. Wydawało się Ukraińcom, że odnieśli wielki sukces dyplomatyczny doprowadzając do tego, że Ukraińska Republika Ludowa została uznana przez państwa centralne i dopuszczona do obrad brzeskich jako samodzielny podmiot prawa międzynarodowego ${ }^{4}$.

49 lutego 1918 r. Ukraina zawarła z państwami centralnymi traktat pokojowy (tzw. chlebowy). Sowiecka Rada Komisarzy Ludowych została zmuszona do uznania (17/04.12.1917) niepodległości Ukrainy. W tajnym protokole uzupełniającym państwa centralne godziły się na włączenie Chełmszczyzny i Podlasia do Ukrainy, zaś Austro-Węgry wyrażały zgodę na połączenie w jeden kraj ko- 
W efekcie na arenie międzynarodowej URL była postrzegana jako wróg Ententy, a po porażce państw centralnych w wojnie znalazła się w izolacji dyplomatycznej. Papierowe jedynie uznanie przez sowietów niepodległości Ukrainy powodowało, że agresja bolszewicka na Ukrainie trwała w najlepsze.

Po listopadzie 1918 r. wojnę prowadziły nadal nie tylko Rosyjskie Imperium „,białe” oraz Rosyjskie Imperium „,czerwone”, lecz także wojnę wznowiło Imperium Osmańskie. Jak powszechnie wiadomo, stosunki turecko-rosyjskie były skrajnie wrogie od zawsze. Stosunki Rosji z Turcją uległy zaś zmianie po powstaniu ruchu narodowowyzwoleńczego Mustafy Kemala Paszy. Ujęty w traktat z Sèvres rozbiór Imperium Osmańskiego planowany był i zrealizowany miał być wszak bez udziału Rosji bolszewickiej, ale przez państwa ,imperialistyczne”, które dla czerwonej Rosji były wrogami. W ten sposób dwaj odwieczni wrogowie Turcja i Rosja czerwona (ale tylko czerwona) - znalazły się jak gdyby po jednej stronie barykady. Geograficznie zaś jedynym miejscem styku było Zakaukazie i Kaukaz, toteż nic dziwnego, że jeśli miało dojść do porozumienia obu państw, to w sposób naturalny teren ten stałby się zakładnikiem i miejscem targów terytorialnych bez udziału narodów tam żyjących. Nacjonalizm turecki kemalistów z istoty swej odrzucał turanizm, panturkizm, pansilamizm, a więc idee, które mogłyby być groźne dla bolszewickiego odbudowywania byłego carskiego imperium, tym razem pod czerwonym sztandarem. To nowość w polityce na styku Europy i Azji.

Najwcześniej (kwiecień 1920) władza komunistyczna została siłami 11. armii Armii Czerwonej zaprowadzona w Azerbejdżanie. Kolej przyszła na Armenię. We wrześniu (23.09.1920) Turcja zaatakowała Armenię z zaskoczenia i dużymi siłami. Siły tureckie wspomagała Armia Radziecka; dwa potężne państwa i odwieczni wrogowie wspólnie napadli na małą Armenię. W ten sposób Turcja i Rosja - zaciekli wrogowie od zawsze - wspólnymi siłami dokonali rozbioru małej, dzielnie walczącej Armenii. Polakom nie może się to nie kojarzyć z późniejszym paktem Ribbentrop-Mołotow.

Na drugim końcu czerwonego imperium skończyła się wojna z Polską. Teraz przyszła kolej na Gruzję. Jak wiadomo, przed świtem 12 lutego 1921 r. silna 11. armia Armii Czerwonej, dowodzona przez Michała Lewandowskiego, a składająca się w znacznym stopniu z „kryminalistów i bandytów” (S. Ordżonikidze), wyrzutków społecznych, uderzyła na Gruzję wychodząc z Armenii. 18 marca 1921 r. rząd Demokratycznej Republiki Gruzji oraz członkowie akredytowanych

ronny Galicji Wschodniej i Bukowiny oraz na utworzenie autonomicznej prowincji ukraińskiej. Oczywiście w ramach Austrii, bo przecież umawiające się strony liczyły na zwycięstwo państw centralnych w wojnie światowej. Zarówno sprawa oderwania Chełmszczyzny przypominająca bolesny rok 1912, jak i - ujawniony w maju 1918 r. - tajny traktat dotyczący ukraińskiej autonomii w Galicji Wschodniej, wywołały takie wrzenie i manifestacje ludności polskiej, że Austro-Węgry wycofały się z ustaleń tajnego protokołu unieważniając go. 
przedstawicielstw innych krajów drogą morską opuścili kraj. To był koniec nie tylko Demokratycznej Republiki Gruzji, lecz także w ogóle koniec niezawisłego kraju na Kaukazie i Zakaukaziu na siedemdziesiąt lat.

Kemalowska Turcja i jej ruch narodowy - jak wiadomo - odniosły sukces. Traktat w Lozannie (1923) anulował wszystkie dotkliwe dla Turcji wcześniejsze ustalenia, w tym także terytorialne, z krzywdą dla Armenii.

\section{LIBERALIZM I DEMOKRACJA A TOTALITARYZM}

Od czasów francuskiej rewolucji z jej Deklaracją Praw Człowieka i Obywatela i później kodeksu cywilnego Francuzów, zaś, po drugiej stronie oceanu, od amerykańskiej konstytucji - wydawało się, że zachodni świat cywilizowany z każdym dziesięcioleciem zmierza w kierunku liberalizmu. Koniec pierwszej wojny światowej ten kierunek przerwał. Wprawdzie wojna i rewolucja w połączeniu z wcześniejszymi rozbudzeniami narodowymi i nawet nacjonalizmem skutkowały pojawieniem się na mapie Europy Środkowo-Wschodniej - między Niemcami a Rosją - państw narodowych nieistniejących przed 1914 r. ${ }^{5}$, ale zważmy, że znaczna ich część miała ustroje polityczne stające się - prędzej lub nieco później - antynomią ustrojów liberalnych. Węgry, Rumunia, Bułgaria, Grecja, Turcja przekształcona z Imperium Osmańskiego to dyktatury. Inne ${ }^{6}$ pójdą w ich ślady lub przynajmniej w kierunku autorytaryzmu. Natomiast faszyzm, nazizm i komunizm to szczególne zjawiska w dziejach ludzkości. Tylko Wielka Brytania, Francja, Belgia, Holandia, Szwajcaria i Skandynawia (bez Finlandii) utrzymały formę ustrojową demokratyczno-liberalną. Jednocześnie koniec pierwszej wielkiej wojny musiał skutkować poszerzaniem obszarów demokracji: trudno byłoby sobie wyobrazić, by masom wracających z frontu żołnierzy nie dać pełni praw politycznych (wszak to zadecydowało o zwycięstwie bolszewików i rozprzestrzenianiu komunistycznej utopii w Europie). Podobnie trudno było nadal nie dopuszczać kobiet do życia publicznego, skoro w la-

${ }^{5}$ Nowych państw lub w nowym kształcie pojawiło się w tym obszarze dziewięć: Polska, Austria, Węgry, Czechosłowacja, Litwa, Łotwa, Estonia, Finlandia, Jugosławia („Królestwo Serbów, Chorwatów i Słoweńców”) wraz z wcześniej istniejącymi Serbią i Czarnogórą, a ponadto Rumunia dwukrotnie zwiększyła swoją powierzchnię, a to kosztem ziem należących poprzednio do Austro-Węgier oraz Rosji. J. Holzer, Europa wojen 1914-1945, Warszawa 2008, s. 148.

${ }^{6}$ Wydarzenia: 1923 nacjonalistyczny przewrót w Bułgarii; ten sam rok (1923) - królewski zamach stanu w Hiszpanii (gen. Primo de Rivera); 1926: zamach majowy w Polsce, zamach marszałka Carmony w Portugalii (rządy Salazara od 1932), zamach Smetony na Litwie; 1930-1931 w Finlandii zamach konserwatywnej prawicy; 1934 ustanowienie reżimu autorytarnego w Austrii, prawicowy zamach stanu Ulmanisa na Łotwie, ten sam rok (1934) zamach Pätsa w Estonii; 1935 przewrót wojskowy w Republice Greckiej; 1936 rebelia wojskowa w Hiszpanii i wojna domowa; 1938 królewski zamach stanu w Rumunii. J. Baszkiewicz, Powszechna historia ustrojów państwowych, Gdańsk 1998, s. 343-344; zob. też J. Holzer, Europa wojen..., s. 280 i n. 
tach wojny zmuszone były one dźwigać jej ciężary we wszystkich sferach życia społecznego i prywatnego (znamienne, że najpóźniej prawa wyborcze kobietom przyznała omijana przez wojny i rewolucje Szwajcaria - 1971). Demokracja po I wojnie początkowo zawitała do Niemiec (konstytucja weimarska, 1919 r.) oraz do Austrii (konstytucja, 1920 r.). To właśnie ta demokracja pozwoliła w republice weimarskiej zwyciężyć nazistom na czele z Austriakiem.

Po strasznej wojnie, za którą przeciętny, a ciężko doświadczony człowiek łatwo obwiniał rządzących, demokracja wydawała się receptą na lepszy świat; świat demokratyczny, czyli rządzony przez wszystkich. Dużo w tym myśli utopijnej, a to z kolei niosło rozczarowania, te zaś łatwo mogły u części opinii publicznej rodzić przekonanie, że najlepiej siłą zlikwidować wszystko, co nam się nie podoba, bo jest krzywdzące, ,złe”. Wielki kryzys gospodarki kapitalistycznej pierwszej połowy lat 30. przy jednoczesnych sukcesach gospodarczych Niemiec i Włoch wydawały się to rozumowanie potwierdzać.

Bulwersująca może się wydać następująca teza: to w znacznym stopniu (ale nie wyłącznie) ciągnące się z XIX w. idee liberalizmu oraz demokracji skutkowały dramatycznym przedłużeniem pierwszej wojny światowej w drugą wojnę światową. Wszak główni odpowiedzialni za drugą wojnę byli naziści i niektórzy inni dyktatorzy, którzy (z wyjątkiem „,zerwonego imperium rosyjskiego”) doszli do władzy w sposób demokratyczny w państwach tak liberalnych, że gloryfikacja przemocy i pogarda dla państwa prawa, fascynacja wojną jako środkiem uprawiania polityki narodowej - były w tych krajach dopuszczalne i zyskiwały autentyczne poparcie mas. Szokujące, ale nie nowe jest stwierdzenie, że pełna demokracja to system polityczny wyraźnie niedobry, a może nawet fatalny.

Wraca więc postawione wcześniej pytanie, czy 18 marca 1921 r. to był koniec wojny światowej? A może to tylko przerwa w wojnie? Łatwo zauważyć, że II wojna światowa zupełnie tak samo jak pierwsza, miała charakter imperialny. Została zainicjowana $\mathrm{z}$ tej samej strony: przez Niemców (w pełni wliczając w to Austriaków), wspieranych przez słabych, ale pełnych imperialnego pożądania Włochów. Pakt Ribbentrop-Mołotow jaskrawo wykazał, że wojna w najmniejszym stopniu nie miała charakteru ideologicznego, jak to się chce niekiedy podnosić. Na drugim biegunie postawy i zachowania Szwecji oraz Irlandii (osobno IRA), a także Hiszpanii i kolaborującej Francji też nieco wzmacniają stanowisko o nieideologicznym charakterze drugiej wojny światowej jako imperialnej kontynuacji pierwszej.

Za tezą o drugiej wojnie jako dalszym ciągu pierwszej wydaje się także przemawiać argument, że to stworzony przez zwycięzców system wersalski (w całej szerokiej złożoności ${ }^{7}$ ) był współwinny przyszłym wydarzeniom. Główni twór-

\footnotetext{
${ }^{7}$ Chodzi o traktaty nie tylko w Wersalu z Niemcami (28.04.1918), lecz także z Austrią w Saint-Germain (10.09.1918), z Bułgarią w Neuilly (27.09.1918), z Węgrami w Trianon (04.06.1919),
} 
cy systemu wersalskiego - Amerykanie z prezydentem Wilsonem - wycofali się z niego i ze spraw europejskich jeszcze przed wejściem systemu w życie. Nie wydaje się natomiast, by dla dalszego biegu wydarzeń miało większe znaczenie wyłączenie z systemu wersalskiego Rosji (ZSRR), bowiem dla bolszewików wszelkie układy miały znaczenie kartki papieru. Przypomnieć przy tym warto, że już raz czerwona Rosja sprzymierzyła się z kemalowską Turcją (kosztem Armenii) przeciwko imperialistom dyktującym warunki po I wojnie. Turcja wówczas wygrała. Z kim miałyby się sprzymierzyć pokonane i upokorzone po 1919 r. Niemcy, jak nie z czerwoną Rosją, która $\mathrm{z}$ I wojny wyszła też w granicach okrojonych wobec stanu sprzed 1914 r. i z niezrealizowanymi marzeniami o rewolucji światowej? Jak bardzo ważne były po pierwszej wojnie siły nacjonalistyczne, u których pojawiło się - uzasadnione lub wyimaginowane - poczucie krzywdy i niespełnionych oczekiwań ${ }^{8}$ o tym pisać nie trzeba, bo to sprawa powszechnie znana.

Zakończenie pierwszej oraz drugiej wojny światowej było wielce odmienne, co do formy prawnej oraz skutków ustrojowych.

\section{WOJNY XX WIEKU A PRAWO MIĘDZYNARODOWE PUBLICZNE}

Prawo międzynarodowe publiczne, zwane także prawem narodów, wykazuje ścisły związek z wojną od początku kształtowania się tej stosunkowo młodej gałęzi prawa. Ograniczmy się tu do przypomnienia, iż dla rozwoju tego prawa wielkie znaczenie miały rozważania o wojnie sprawiedliwej, zaś Hugo Grocjusz, jeden z twórców tego prawa, wskazywał, że głównym czynnikiem wpływającym na jego rozwój była wojna. W tym kontekście należy odnotować, iż przed I wojną światową doszło do unormowania $(1899,1904,1907)$ międzynarodowego prawa wojny, gdy z inicjatywy m.in. Rosji i USA opracowano 13 konwencji haskich, stanowiących w istocie kodyfikację międzynarodowego prawa konfliktów zbrojnych. Zawarta preambule do IV konwencji haskiej z 1907 r. tzw. klauzula Martensa stanowiła, że w sytuacjach nieobjętych przepisami konwencji ludność i strony wojujące znajdują się pod opieką i władzą zasad prawa narodów, wypływających ze zwyczajów, ustanowionych między cywilizowanymi narodami oraz z zasad

\footnotetext{
z Turcją w Sẻvres (10.08.1920) i zrewidowany później w Lozannie (24.07.1923). J. Holzer, Europa wojen 1914-1945, Warszawa 2008, s. 148.

${ }^{8}$ To nie tylko Niemcy i Austria (której zwycięzcy nawet zabronili myśleć o połączeniu z Niemcami i zabronili używania nazwy „Republika Niemiecko-Austriacka”), byłe Imperium Osmańskie, czyli teraz Turcja, także Węgry (z 325 tys. km² stały się krajem o 93 tys.km²), Bułgaria, Włochy i Grecja nie otrzymały tego, co miały obiecane, a Turcja dokonała czystki etnicznej Greków z terenów zachodniej Anatolii, która była domem Greków od czasów starożytnych (J. Baszkiewicz, Powszechna..., s. 346-347). Nieco odrębną kwestią, ale nie wolno jej pomijać, była sprawa krótkotrwałej Ukraińskiej Republiki Ludowej oraz ZURL.
} 
humanitarnych i wymagań społecznego sumienia ${ }^{9}$. Była ona wyrazem naiwnej wiary, iż wojnę można prowadzić w sposób cywilizowany oraz przepisany przez prawo. Przebieg I wojny tego zapatrywania nie potwierdził. Nie oznacza to jednak, iż konwencje haskie nie odegrały pozytywnej roli; nadal są podstawą dzisiejszego prawa konfliktów zbrojnych. Wśród wykształconych w okresie Wielkiej Wojny idei należy na czołowym miejscu wymienić koncepcję prawa samostanowienia narodów. Jednym z jej pierwszych praktycznych przejawów były plebiscyty w sprawie przynależności do powstającego państwa włoskiego w latach $1859-1870^{10}$. Jednak podczas I wojny pojawiły się nowe elementy tej koncepcji. Prezydent Thomas Woodrow Wilson zadeklarował w maju 1916 r. w Kongresie USA: „każdy naród ma prawo wybrać suwerenność, pod którą będzie żyć”. W tym samym przemówieniu stwierdzał: „małe państwa świata mają takie samo prawo do korzystania ze swej suwerenności i integralności terytorialnej, jak wielkie mocarstwa; tego oczekują i na to nalegają". Myśli te rozwinął w styczniu 1917 r., gdy w mowie do Kongresu stwierdzał, że żaden pokój nie będzie trwały, jeśli nie będzie się opierał na uznaniu i akceptowaniu zasady, że „rządy wywodzą całą swoją sprawiedliwą władzę od przyzwolenia rządzonych i nie istnieje prawo pozwalające na odstępowanie ludów przez jednego władcę drugiemu, jakby to była ich prywatna własność" ${ }^{11}$. Warto w tym miejscu zauważyć, że ówcześnie Stany Zjednoczone nie były powiązane żadnym krępującymi je układami z żadnym krajem Starego Kontynentu; zupełnie przeciwnie było z krajami europejskimi, dla których układy, traktaty stanowiły ograniczenia w wypowiadaniu takich idei.

Władze radzieckie używały haseł o samostanowieniu narodów oraz uznawały względnie potwierdzały uznanie suwerenności albo niepodległości danego narodu, a czyniły to jedynie po to, by mieć argument przeciwstawny polityce białych (najpierw Rządu Tymczasowego, następnie Kołczaka, Denikina $i$ innych) oraz przeciwstawny polityce okupacyjnej niemieckiej albo tureckiej. Tak było w grudniu 1917 roku, kiedy to rząd radziecki w Piotrogrodzie uznał niepodległość Ukrainy, Finlandii oraz radzieckich republik (!) Estonii, Łotwy i Litwy, a także wydał dekret $O$ tureckiej Armenii, w którym uznawał prawo Armenii w części okupowanej przez Turcję do samookreślenia się. Lenin jeszcze u progu I wojny światowej (1914) zdecydowanie odrzucał koncepcję federacyjnej formy państwa, nie zaaprobował też autonomii terytorialnej. Leninowska wizja około 1914 roku była dychotomiczna: internacjonalizm kontra nacjonalizm. Słowo „patriotyzm” w ogóle się nie pojawia. Kiedy już wojna wybuchła,

\footnotetext{
9 Konwencja dotyczaca praw i zwyczajów wojny lądowej, ratyfikowana przez Polskę w 1927 r., Dz.U. Nr 21, poz. 161.

${ }^{10}$ L. Zieleniewski, Plebiscyt w prawie narodów, Warszawa 1928, s. 33-36, 43-44.

${ }^{11}$ Cyt. za: J. Quigley, Soviet Legal Innovation and the Law of the Western World, Cambridge (US) 2007, s. 138 .
} 
przypomniał, że robotnicy nie mają ojczyzny i wzywał do działania na rzecz klęski własnego kraju, bowiem miało to ułatwić rewolucję. Pragmatyczny, zaczął doceniać siłę ruchów narodowych, ale chciał ją spożytkować dla celów rewolucji. Socjaliści powinni popierać ruchy narodowe, „by przyspieszyć obalenie wspólnego wroga, ale niczego nie oczekują dla siebie od tych chwilowych sprzymierzeńców ani nie czynią im żadnych ustępstw"; to jest istota poglądów Lenina jeszcze przed 1903 rokiem $^{12}$.

Stanisław Estreicher już w 1917 r. wyrażał sceptycyzm wobec możliwości realizacji tej koncepcji według „formułki bolszewickiej”, podobnie zresztą jak i koncepcji T.W. Wilsona ${ }^{13}$. Trafnie jednak zauważał, że plebiscyty w sprawie przynależności państwowej danego terytorium będzie można zrealizować jako postanowienia przyszłej konferencji pokojowej. Jak wiemy, traktat wersalski przewidywał przeprowadzenie plebiscytów w Szlezwiku-Holsztynie, Zagłębiu Saary, na Górnym Śląsku, Mazurach oraz Powiślu. Ostatecznie traktat wersalski nie uznawał samostanowienia narodów jako zasady prawa międzynarodowego (uczyniła to dopiero Karta Narodów Zjednoczonych z 1945 r. w art. 1), jednak to I wojna światowa była ważnym czynnikiem tworzącym tę zasadę. Jako element upowszechniania się koncepcji samostanowienia narodów widzieć należy stworzony przez traktat wersalski system mandatowy. Zostały nim objęte dawne terytoria tureckie na Bliskim i Środkowym Wschodzie oraz niemieckie kolonie w Afryce. Mandaty, tj. prawo zarządzania danym terytorium, powierzono Francji i Wielkiej Brytanii. Jednocześnie traktat wersalski w art. 22 podkreślał, że mandaty mają charakter tymczasowy i są etapem na drodze do pełnej niepodległości danych terytoriów, zaś rolą mandatariusza miało być doprowadzenie danego terytorium do niepodległego bytu. System mandatowy spotkał się z powszechną krytyką w nauce jako kolejna forma kolonializmu. Nie sposób jednak zaprzeczyć, że stanowił on etap w kierunku pełnej niepodległości, która na niektórych terytoriach mandatowych nastała wkrótce po II wojnie światowej.

Prezydent Wilson jest twórcą idei powstania organizacji międzynarodowej grupującej wszystkie państwa, zadaniem której miało być utrzymanie międzynarodowego pokoju i bezpieczeństwa. Organizacją tą była Liga Narodów, powołana do życia przez pierwszych 26 artykułów traktatu, stanowiących Pakt Ligi Narodów ${ }^{14}$. Również to dzieło traktatu wersalskiego historia oceniła negatywnie, gdyż Liga Narodów nie zapobiegła wybuchowi kolejnej, jeszcze

${ }^{12}$ Cyt. za R. Pipes, Czerwone imperium. Powstanie Zwiazku Sowieckiego, Warszawa 2015, s. 37 .

${ }^{13}$ S. Estreicher, Samostanowienie ludów, [w:] Konserwatyzm krakowski. Wybór pism, Kraków 2012, s. 122-125.

${ }^{14}$ Tekst polski: Traktat pokoju między mocarstwami sprzymierzonemi i skojarzonemi i Niemcami, podpisany w Wersalu dnia 28 czerwca 1919 roku, Dz.U. z 1920 r. nr 35, poz. 200. 
straszliwszej wojny światowej. To prawda. Trzeba jednak wziąć pod uwagę fakt, iż powstanie Ligi Narodów otworzyło nowy rozdział w dziejach prawa międzynarodowego publicznego. Ujął to trafnie sekretarz generalny ONZ Sithu U Thant w odczycie z roku 1964: „Zanim powstała LN, prawie powszechnym było przekonanie, że każde państwo jest jedynym suwerennym sędzią swoich czynów, pozostaje więc nieczułe na wszystkie kroki i zastrzeżenia innych państw. Idea - dziś generalnie przyjęta - iż wspólnota narodów posiada prawo moralne i sądowe dyskutowania i osądzania zachowania się międzynarodowego swoich członków, nie znajdowała się w żadnym traktacie i w żadnej instytucji przed Paktem LN. Od tej chwili zaczyna się idea, dziś powszechnie przyjęta, że wojna napastnicza jest zbrodnią przeciw Ludzkości i że każde państwo ma zainteresowanie, obowiązek i prawo sprzymierzenia się z innymi państwami celem zapobieżenia jej"15. Wskazanie, że ostatecznym suwerenem jest społeczność międzynarodowa, a nie państwa, otworzyło całkowicie nowe horyzonty dla tej gałęzi prawa.

Charakterystycznym aspektem zmian w prawie międzynarodowym publicznym po I wojnie światowej jest stopniowa likwidacja przywilejów kolonialnych, wyrażająca się w rezygnacji mocarstw z przywilejów eksterytorialności i immunitetów, przysługujących mocarstwom i ich obywatelom na terytoriach Imperium Osmańskiego, Chin, Persji i innych. Proces dekolonizacji znacznie przyspieszy po II wojnie i będzie się po części wiązał z zimną wojną.

\section{OCHRONA MNIEJSZOŚCI NARODOWYCH. PROBLEM ROZBROJENIA}

Gdy mowa o ładzie wersalskim jako rezultacie wojny, nie można pominąć próby stworzenia pierwszego systemu ochrony mniejszości narodowych w postaci tzw. małego traktatu wersalskiego lub traktatu mniejszościowego ${ }^{16}$. Nie chodziło tu jedynie o prawa mniejszości narodowych, ale - co było wielką nowością przewidziane przez traktat mechanizmy ich ochrony w ramach Ligi Narodów. W ten sposób mniejszość narodowa stawała się podmiotem prawa międzynarodowego. Otwierało to nowy rozdział w rozwoju prawa narodów, niezależnie od ciągle podkreślanych wad wersalskiego systemu ochrony mniejszości, takich jak np. nierówność państw.

${ }^{15}$ Cyt. za: E.J. Osmańczyk, Encyklopedia ONZ i stosunków międzynarodowych, Warszawa 1982, s. 301.

${ }^{16}$ Dz.U. z 1920 r. nr 35, poz. 199. 
Wskazane wyżej nowe elementy ładu prawnego powstałego w związku z wielką wojną nie wyczerpują oczywiście tematu. Można by na przykład zastanawiać się nad problemem rozbrojenia, podjętym w dwudziestoleciu międzywojennym. Nie sposób nie zauważyć, że wiara w skuteczność systemu wersalskiego stopniowo słabła. Podejmowano próby uratowania tego porządku, a wśród nich zwrócić uwagę należy na tzw. pakt Brianda-Kelloga z 1928 r., zwany także traktatem paryskim lub traktatem przeciwwojennym ${ }^{17}$. Traktat zawiera (obowiązuje nadal) jedynie trzy krótkie artykuły: potępia wojnę i zawiera deklarację wyrzeczenia się wojny agresywnej (art. 1), mówi o pokojowym rozwiązywaniu sporów (art. 2) oraz określa normy dotyczące ratyfikacji i czasu obowiązywania (art. 3). Warto podkreślić, że ratyfikowały go Stany Zjednoczone, w przeciwieństwie do traktatu wersalskiego. Niezależnie od faktu, iż nie zapobiegł on wojnie, należy pamiętać, że jest on ważnym krokiem w kierunku całkowitego potępienia jakiejkolwiek wojny.

Powstaje pytanie, czy II wojna światowa wywarła równie wielki wpływ na rozwój prawa, jak Wielka Wojna. Nie zawarto przecież traktatu pokojowego porównywalnego w wersalskim, zaś stworzony przez Roosevelta i Churchilla wzniośle brzmiący dokument pod nazwą Karty Atlantyckiej (sierpień 1941) trzeba nazwać przejawem cynizmu, skoro ludobójca Stalin otrzymał wówczas od Roosevelta i Churchilla niemal wszystko, czego chciał, i zamknął liczne narody za żelazną kurtyną. Okrucieństwa wojny na czele z Holokaustem stały się jednak impulsem dla rozwoju prawa przeciwwojennego oraz dla jednoznacznego potępienia i zapowiedzi ścigania zbrodni ludobójstwa i zbrodni przeciw ludzkości. Warto pamiętać, że już traktat wersalski nakazywał państwom ścigać swoich zbrodniarzy wojennych (miał się odbyć proces byłego cesarza Wilhelma II), ale właściwie nic $\mathrm{w}$ tym kierunku nie zrobiono. Trzeba więc było zbrodni nieporównanie straszliwszych, by stworzyć międzynarodowy system ich ścigania. Nie sposób jednak nie zauważyć, że w wielu aspektach prawa międzynarodowego mieliśmy do czynienia jedynie z udoskonaleniem rozwiązań powstałych po wielkiej wojnie. Najlepszym tego przykładem jest ONZ, którego Karta stara się eliminować niedoskonałości Paktu Ligi Narodów. Przykładowo, w wyniku II wojny nastąpiło dalsze ograniczenie prawa do wojny. Preambuła Karty Narodów Zjednoczonych zawiera stwierdzenie, że „ludy Narodów Zjednoczonych” są zdecydowane „,zapewnić poprzez przyjęcie zasad i ustalenie metod, aby siła zbrojna używana była wyłącznie we wspólnym interesie"18.

17 Ratyfikowany przez Polskę: Dz.U. z 1929 r. nr 11, poz. 88, tekst w: Dz.U. z 1929 r. nr 63, poz. 489.

${ }^{18}$ Cyt. za: R. Bierzanek, Wojna a prawo międzynarodowe, Warszawa 1982, s. 10. 


\section{ZBRODNIE MIĘDZYNARODOWE ${ }^{19}$. ZBRODNIARZE WOJENNI ${ }^{20}$}

Z końcem obu wielkich wojen musiał znowu (sprawa nie jest nowa) powstać problem prawny ścigania zbrodniarzy wojennych ${ }^{21}$ oraz ich ukarania przez społeczność międzynarodową.

Stanęło przed nią zadanie praworządnego rozwiązania splotu co najmniej trzech problemów: podsądności, czyli kompetencji określonych sądów względem osób, skonstruowania stosownych przepisów karnych, ponieważ dotychczasowe okazywały się niewystarczające wobec skali i zakresu zjawisk totalnej wojny, ponadto retroaktywności tych przepisów (po pewnym czasie pojawi się kwestia przedawnienia tych zbrodni), wreszcie problem odpowiedzialności funkcjonariuszy reżimów faszystowskich i żołnierzy za czyny zgodne z prawem w ich krajach, ale zbrodnicze w powszechnym rozumieniu. Kwestia praworządności rozstrzygnięcia tych zagadnień była pierwszorzędnej wagi, ponieważ właśnie praworządność miała odróżniać zwycięzców od pokonanych barbarzyńców.

Zagadnienie odpowiedzialności za naruszenia prawa konfliktów zbrojnych, dawniej podnoszone tylko w piśmiennictwie i myśli prawniczej, na przełomie XIX i XX wieku zaczęło ewoluować od prawa zwyczajowego w kierunku prawa umownego (konwencje haskie z 1889 i 1907 roku). Spośród 13 konwencji haskich z 1907 r. najważniejsza IV, dotycząca praw i zwyczajów wojny lądowej, zobowiązywała państwa tylko do wypłacania odszkodowań oraz do uzupełnienia własnych ustawodawstw o przepisy obligujące do pociągnięcia sprawców zbrodni do odpowiedzialności przed własnymi sądami. Konwencje haskie nie zawierały definicji zbrodni czasu wojny ani nie określały procedury, ani sankcji22.

Pierwsza wojna światowa znacznie pobudziła proces tworzenia prawa międzynarodowego dotyczącego odpowiedzialności za zbrodnie. Zadecydował o tym zarówno barbarzyński sposób prowadzenia działań, jak też szokujący ogrom

${ }^{19}$ K. Wolfke Zbrodnie międzynarodowe, [w:] E. Smoktunowicz (red.), Wielka encyklopedia prawa, Białystok - Warszawa 2000, s. 1267.

${ }^{20}$ Tym skrótem myślowym będziemy określali trzy rodzaje zbrodni i zbrodniarzy, tak jak to zostało ujęte w porozumieniu z 8 sierpnia 1945 r., zawierającym statut Trybunału Norymberskiego: 1) zbrodnie przeciwko pokojowi, polegające na planowaniu i prowadzeniu wojny napastniczej, 2) zbrodnie wojenne, tj. ciężkie naruszenie praw i zwyczajów wojennych, 3) zbrodnie przeciwko ludzkości, obejmujące morderstwa, akty eksterminacyjne, deportacje i inne czyny nieludzkie przeciwko ludności cywilnej. K. Wolfke, Zbrodnie międzynarodowe..., s. 1267. Tamże zob. o dalszym rozwinięciu norm prawa międzynarodowego w tej sprawie.

${ }^{21}$ J. Nowakowska-Małusecka w wypowiedzi pisemnej do A. Lityńskiego: „zbrodnie wojenne to bezprawne akty kierowane przeciwko osobom i dobrom chronionym przez międzynarodowe prawo humanitarne, jak np. zabijanie jeńców wojennych, masowe egzekucje, gwałty, rabunek cudzej własności, niszczenie dóbr kultury itp.”

${ }^{22}$ T. Kegel, Odpowiedzialność za przestępstwa wojenne $w$ świetle prawa międzynarodowego, „Acta Universitatis Wratislaviensis” 1987, nr 927, prawo CLIV, s. 246. 
strat i cierpień, także wśród ludności cywilnej. W rezultacie traktat wersalski był ważnym krokiem naprzód: zawierał specjalny rozdział „sankcje”, ustalił katalog 31 przestępstw wojennych oraz zobowiązywał do sądzenia niemieckich przestępców wojennych przez trybunały aliantów. Te postanowienia nie zostały wcielone $\mathrm{w} \dot{z} y \mathrm{cie}^{23}$, ale traktat wersalski był pierwszą umową międzynarodową, która ustanowiła zasadę odpowiedzialności karnej jednostek za zbrodnie, w tym także przywódców państw za wywołanie wojny i naruszenie traktatów. Przyjęty przez 60 państw (w tym Niemcy i Japonię) wspomniany już wcześniej Pakt Brianda-Kelloga (1928) zawierał wyrzeczenie się wojny jako środka rozstrzygania sporów, a więc zdelegalizował wojnę; już samo rozpoczęcie działań wojennych stało się przestępstwem międzynarodowym, a w konsekwencji zbrodnią przeciwko pokojowi było samo planowanie, przygotowanie, prowadzenie wojny napastniczej $^{24}$. Ustanowiony przez Pakt Ligi Narodów Stały Trybunał Sprawiedliwości Międzynarodowej (1920-1946) powołany był do rozstrzygania sporów między państwami.

Niejako na marginesie warto przypomnieć, że władze polskie na uchodźstwie położyły niemałe zasługi w zakresie gromadzenia dowodów zbrodni wojennych oraz w przedmiocie tworzenia prawa krajowego w tym zakresie ${ }^{25} .30$ marca 1943 r. Prezydent RP na Uchodźstwie wydał dekret o odpowiedzialności karnej za zbrodnie wojenne (Dz.U. RP Londyn, cz. I, nr 3, poz. 6), który był pierwszym na świecie krajowym aktem legislacyjnym w przedmiocie zbrodni wojennych. Pierwszym aktem prawa karnego komunistycznej władzy w Polsce był dekret z 31 sierpnia 1944 r. o „wymiarze kary dla faszystowsko-hitlerowskich zbrodniarzy winnych zabójstw i znęcania się nad ludnością cywilną i jeńcami oraz dla zdrajców Narodu Polskiego" (Dz.U. nr 4, poz. 16; pięciokrotnie nowelizowany ${ }^{26}$. Jak wiadomo, dekret ustalił odpowiedzialność karną również

\footnotetext{
${ }^{23}$ Jak wiadomo, cesarz Wilhelm II wyjechał do Holandii, a ta odmówiła wydania go. Nie niepokojony mieszkał tam do śmierci (1941) uprawiając ogródek. W traktacie wersalskim Niemcy zobowiązały się do wydania przyszłemu trybunałowi wszystkich przestępców wojennych umieszczonych przez aliantów na specjalnej liście. Kiedy jednak alianci dostarczyli taką listę liczącą 901 nazwisk, władze niemieckie kategorycznie odmówiły ekstradycji. W rezultacie alianci zgodzili się (notą z 13.02.1920 r.), by sprawy niemieckich zbrodniarzy wojennych rozpatrzyły sądy niemieckie. Najwyższy Trybunał w Lipsku spośród 901 osób z listy alianckiej skazał zaledwie 13 osób na kary więzienia od 6 miesięcy do 4 lat. T. Kegel, Odpowiedzialność za przestępstwa wojenne..., s. 247; J. Nowakowska-Małusecka, Odpowiedzialność karna jednostek za zbrodnie popetnione w bytej Jugosławii i w Rwandzie, Katowice 2000, s. 17.

${ }^{24}$ J. Nowakowska-Małusecka, Odpowiedzialność karna..., s. 17; T. Kegel, Odpowiedzialność za przestepstwa wojenne..., s. 247-248.

${ }^{25}$ Szczegółowo zob. E. Rojowska, Komisja Narodów Zjednoczonych do spraw Zbrodni Wojennych i działalność Polski w ramach jej prac: zarys problemu, „Studia Prawnoustrojowe”, Olsztyn 2013, nr 22, s. 15-27.

${ }^{26}$ Zob. A. Lityński, Historia prawa Polski Ludowej, Warszawa 2013, s. 115.
} 
za sam udział „w organizacji przestępczej, powołanej lub uznanej przez władze państwa niemieckiego lub z nim sprzymierzonego", co było zgodne z późniejszymi ustaleniami wyroku Międzynarodowego Trybunału Wojskowego w Norymberdze. Warto zauważyć, że między 17 września 1939 r. a 22 czerwca 1941 r. ponad połowa terytorium Polski była okupowana przez ZSRR i to państwo było sprzymierzone z III Rzeszą. „Sierpniówka” była jednym z pierwszych na świecie aktów prawa karnego, dotyczących odpowiedzialności za zbrodnie wojenne w okresie drugiej wojny światowej. Jako jedyny z wczesnych aktów karnych częściowo (art. 1 ust. 1) obowiązuje nadal, co wiąże się także z uchwaloną 26 listopada 1968 r. przez Zgromadzenie Ogólne ONZ konwencją potwierdzającą niestosowanie przedawnienia zbrodni wojennych i zbrodni przeciw ludzkości. Postanowienia tej konwencji odnoszą się także do niestosowania przedawnienia w przypadku zbrodni ludobójstwa.

Odrębną kwestią, która pojawiła się po długotrwałej wojnie totalnej, było ukaranie tych, którzy przeszli na stronę wroga albo tych, którzy wrogowi służyli, albo tych, którzy wyparli się swojej narodowości i zadeklarowali wrogą narodowość. A przypomnieć warto, że w stalinowskim ZSRR zdrajcą był niemal każdy żołnierz, który dał się wziąć do niewoli; tacy z niemieckich obozów jenieckich (jeśli je przeżyli) trafiali do sowieckich łagrów.

W akcie bezwarunkowej kapitulacji z 8 maja 1945 r. Niemcy przyjęły wszelkie rozwiązania, jakie zdecydują się wobec nich zastosować zwycięzcy alianci. Werdykt w tej kwestii znalazł się w umowie poczdamskiej (02.08.1945). Wielka Czwórka podpisała (08.08.1945) w Londynie Porozumienie w przedmiocie ścigania i karania głównych przestępców wojennych Osi Europejskiej, a załącznikiem do tego dokumentu była Karta Międzynarodowego Trybunału Wojskowego. W Karcie zawarto podstawowe zasady odpowiedzialności oraz ustanowiono trzy kategorie zbrodni: 1) przeciw pokojowi, 2) wojenne, 3) przeciw ludzkości. Na tej podstawie procedował i orzekał (1945-1946) Międzynarodowy Trybunał Wojskowy w Norymberdze ${ }^{27}$.

Także Japonia skapitulowała bezwarunkowo, przy czym decyzję taką podjął osobiście cesarz i ogłosił ją przez radio. Zgodnie z państwową (1868-1945) religią shinto ${ }^{28}$ - cesarz sam był bogiem. Musiał zatem zaistnieć problem (który

27 Jak wiadomo, Międzynarodowy Trybunał Wojskowy w Norymberdze w okresie od 20.11.1945 r. (pierwsza sesja odbyła się w Berlinie 18.10.1945) do 01.10.1946 r. orzekł w sprawie 22 oskarżonych, z których 12 skazano na karę śmierci (przez powieszenie), 3 na karę dożywotniego więzienia, 4 skazano na pozbawienie wolności na okres od 10 do 20 lat, zaś 3 uniewinniono. Zob. m.in. J. Nowakowska-Małusecka, Odpowiedzialność karna..., s. 19.

${ }^{28}$ Shinto (jap.: „droga bogów”), japońska religia politeistyczna; centralne miejsce zajmuje mit o powstaniu Japonii i ustanowieniu linii cesarskiej; wnuk najwyższego bóstwa - bogini słońca zszedł na wyspę Kiusiu rozpoczynając tym samym ziemską historię cesarstwa; s. była 1868-1945 
zrozumieli Amerykanie): czy bóg może skapitulować. Cesarz został nieco później przymuszony do wyrzeczenia się swojej boskości (w przemówieniu radiowym 01.01.1946), zaś ogłoszona (03.11.1946, z mocą od 03.05.1947) konstytucja wyznaczyła cesarzowi rolę ,symbolu jedności narodu"29. Proces przed Międzynarodowym Trybunałem Wojskowym dla Dalekiego Wschodu w Tokio, powołanym (19.01.1946) zarządzeniem Naczelnego Dowódcy Mocarstw Sprzymierzonych na Dalekim Wschodzie gen. Douglasa MacArthura, na podstawie porozumienia USA, Wielkiej Brytanii, ZSRR, Australii, Kanady, Nowej Zelandii, Francji, Holandii, Chin, do którego później przystąpiły Indie i Filipiny, trwał od 29.04.1946 do 12.11.1948 roku.

Procesy norymberski oraz tokijski ${ }^{30}$ były ważnym precedensem, m.in. potwierdzającym, że normy zawarte w IV Konwencji Haskiej wiążą wszystkie państwa, a nie tylko te, które są stronami Konwencji ${ }^{31}$, gdyż stanowią część prawa zwyczajowego. Na podstawie Ustawy nr 10 Sojuszniczej Rady Kontroli nad Niemcami (20.12.1945) o karaniu osób winnych zbrodni wojennych, zbrodni przeciwko pokojowi i zbrodni przeciwko ludzkości przestępcy, którzy nie byli sądzeni w Norymberdze lub Tokio, stawali przed sądami państw, na terenie których zbrodni dokonali, lub przed sądami niemieckimi.

Te dwa procesy - norymberski oraz tokijski - to pierwsze w dziejach przypadki, kiedy przed międzynarodowymi organami sądowymi stanęły jednostki, odpowiadając za naruszenia prawa międzynarodowego. Wcześniej tylko państwa podejmowały określone zobowiązania i między sobą się z nich rozliczały. Jednostka nie pozostawała $\mathrm{w}$ jakiejkolwiek relacji z prawem międzynarodowym. Jeśli państwo chciało postawić - z tytułu naruszenia reguł prawa międzynarodowego - w stan oskarżenia osoby fizyczne, to czyniło to przed sądami krajowymi i na podstawie prawa wewnętrznego ${ }^{32}$.

religią państwową. J. Herman i T. Herman (red.), Leksykon. Religie, Kościoły, Wyznania, Warszawa 2002, s 203.

${ }^{29}$ J. Tubielewicz, Historia Japonii, Wrocław - Warszawa - Kraków - Gdańsk - Łódź 1984, s. 424.

${ }^{30}$ Międzynarodowy Trybunał Wojskowy dla Dalekiego Wschodu w Tokio w 1948 r. orzekał w sprawie 28 przestępców japońskich, 7 skazując na karę śmierci, 18 na kary więzienia, 3 uniewinnił. Proces toczył się od 29 kwietnia 1946 do 12 listopada 1948 r. K. Karski, D. Świętońska, Proces przed Międzynarodowym Trybunatem Wojskowym dla Dalekiego Wschodu i jego miejsce w świadomości historycznej Japończyków, „Gdańskie Studia Azji Wschodniej” 2013, z. 4, s. 7; T. Kegel, Odpowiedzialność za przestęstwa wojenne..., s. 251; J. Tubielewicz, Historia Japonii..., s. 428.

31 J. Nowakowska-Małusecka, Odpowiedzialność karna..., s. 19.

${ }^{32}$ K. Karski, D. Świętońska, Proces przed Międzynarodowym Trybunałem Wojskowym dla Dalekiego Wschodu..., s. 7. 
Zasady tutaj zasygnalizowane zwane są „zasadami norymberskimi”. Zatwierdzone zostały rezolucją Zgromadzenia Ogólnego ONZ (11.12.1946) ${ }^{33}$. Zasady norymberskie do 1948 r. nie posługiwały się jeszcze pojęciem zbrodni ludobójstwa, które to pojęcie - jak wiadomo - zdefiniował uchodźca z Polski Rafał Lemkin, a ZO ONZ 09.12.1948 r. przyjęło Konwencję o zapobieganiu i karaniu zbrodni ludobójstwa. Jest to odrębna kategoria zbrodni.

Zbrodnie sowieckie w czasie przygotowania i przebiegu II wojny światowej oczywiście były zbrodniami przeciwko pokojowi, zbrodniami wojennymi i zbrodniami przeciwko ludzkości ${ }^{34}$. Komentarza w sprawie ich nieścigania, a nawet zatajania przez aliantów, tutaj nie będzie.

Prace trwały i przyniosły dalszy rozwój międzynarodowego prawa karnego, a m.in. z inicjatywy Polski w 1968 r. przyjęto konwencję o nieprzedawnianiu zbrodni wojennych i zbrodni przeciwko ludzkości. Nie ma powodu dokonywania tutaj rejestracji osiągnięć, poza przynajmniej jedną wzmianką przypominającą, że w XX wieku, po zakończeniu II wojny światowej, w Europie wybuchła tylko jedna wojna, a to w byłej Jugosławii. Skutkowało to powołaniem (25.05.1993) przez Radę Bezpieczeństwa ONZ Międzynarodowego Trybunału Karnego dla byłej Jugosławii3 ${ }^{35}$. W kilkanaście miesięcy później (08.11.1994) Rada Bezpieczeństwa ONZ powołała Międzynarodowy Trybunał Karny dla Rwandy ${ }^{36}$, a to głównie w związku ze stwierdzonym ludobójstwem dokonywanym przez lud Hutu na ludzie Tutsi. Później jeszcze pojawiły się specjalne międzynarodowe sądy karne: Trybunał Specjalny dla Sierra Leone (2002), Nadzwyczajne Izby Sądów w Kambodży (2006), Trybunał Specjalny dla Libanu (2007). Szczególną instytucją jest Międzynarodowy Trybunał Karny w Hadze powołany w 1998 r. na podstawie będącego umową międzynarodową statutu, który wszedł w życie w 2002 r.

Warto przy okazji zwrócić uwagę zarówno na odmienny formalnoprawny sposób zakończenia I oraz II wojny światowej, jak też i na dalszy odmienny sposób postępowania zwycięzców. Po I wojnie zwycięzcy zawarli z pokonanymi imperiami najpierw rozejmy ${ }^{37}$, a potem negocjowali traktaty ${ }^{38}$, co w przypadku Niemiec przebiegało długo i nerwowo. Przegrane było też Imperium Rosyjskie, chociaż ta sprawa jest szczególna, skomplikowana, ale ogólnie znana

${ }^{33}$ Bliżej zob. J. Nowakowska-Małusecka, Odpowiedzialność karna..., s. 21.

${ }^{34}$ Bliższe omówienie zob. P. Kładoczny, Zbrodnie stalinowskie na terytorium II Rzeczypospolitej w latach 1939-45 w świetle prawa norymberskiego, „Studia Iuridica” 1985, t. 27, passim.

${ }_{35}$ J. Nowakowska-Małusecka, Odpowiedzialność karna..., passim.

36 J. Nowakowska-Małusecka, Odpowiedzialność karna..., passim.

${ }^{37}$ Najpierw z Bułgarią (29.09.1918), potem z Imperium Osmańskim (30.10.1918); z Austro-Węgrami (04.11.1918); z Niemcami (11.11.1918).

3828 czerwca 1919 r. z Niemcami w Paryżu; 10 września 1919 r. z Austrią w Saint-Germain; 27 listopada 1919 r. z Bułgarią w Neuilly; 20 czerwca 1920 r. z Węgrami w Trianon; 10 sierpnia 1920 r. z Turcją w Sèvres. (zmieniono go częściowo w Lozannie w roku 1923). 
i tym samym niewymagająca komentarzy. Zwycięzcy narzucali też warunki twarde, zarówno terytorialne, jak i inne: kontrybucje, ograniczenia w zakresie zbrojeń. Efektem były liczne rozczarowania i frustracje: najsilniejsze w Niemczech, ale i na Węgrzech, a także po stronie zwycięzców - we Włoszech. Skutki polityczno-ustrojowe były poważne jeszcze pod koniec wojny (Imperium Rosyjskie, Imperium Osmańskie), szybkie były we Włoszech i na Węgrzech, nieco późniejsze w Niemczech. Natychmiastowe było podjęcie przez Stambuł oraz Moskwę działań zbrojnych, będących w istocie drugą fazą I wojny; bolszewików zatrzymali dopiero Polacy, zaś skomunizowanie Niemiec było o przysłowiowy włos.

Po I wojnie alianci zachodni wyciągnęli wnioski z doświadczeń powojennych, które doprowadziły do narodzin systemów ekstremistycznych - totalitaryzmów. Po II wojnie nie było rozejmów i rokowań pokojowych, tylko bezwarunkowe kapitulacje i narzucenie określonych rozwiązań, nawet jeśli w przypadku Japonii przyjęły one formę traktatu pokojowego (San Francisco, 08.09.195139) kończącego okupację amerykańską. Jednocześnie zachodni alianci, głównie Amerykanie, rozumieli, że dla zatrzymania tendencji odwetowych i ekstremizmów, zwłaszcza ekspansji komunizmu, nie wolno zepchnąc przegranych w trwałą nędzę, ludności w skrajną biedę. Dlatego 3 kwietnia 1948 r. Kongres Stanów Zjednoczonych uchwalił ustawę, w której zawarto podstawowe zasady programu ekonomicznej pomocy dla Europy - European Recovery Program, zwanego od nazwiska swego twórcy Planem Marshalla. Ponadto zimna wojna weszła już w ostrą fazę (wojna w Korei wybuchła 25.06.1950) i USA potrzebowały silnych sojuszników zarówno w Europie, jak i w Azji.

Na marginesie, nie sposób pominąć drogi Francji przez II wojnę światową i po jej zakończeniu. Haniebny rozejm (22.06.1940) był w istocie pełną i upokarzającą kapitulacją tego mocarstwa, które nie miało woli dotrzymania żadnego zobowiązania sojuszniczego ${ }^{40}$. Zdekompletowany parlament na posiedzeniu w Vichy ogromną przewagą głosów (569:80; 20 wstrzymujących się) przyznał Pétainowi pełnię władzy i prawo ustanowienia konstytucji. „To już koniec Trzeciej Republiki. Klęska Francji z 1940 r. nie była tylko pogromem militarnym, ale też całkowitym załamaniem się instytucji politycznych”"41. „Francuzi sami chcieli

39 Bliżej zob. J. Tubielewicz, Historia Japonii..., s. 429-430.

${ }^{40}$ Chodzi nie tylko o zobowiązania sprzed 1 września 1939 r. (w tym zawarte w polsko-francuskim protokole wojskowym z 19.05.1939 r., że „Francja rozwinie działania ofensywne przeciw Niemcom swymi głównymi siłami, począwszy od 15 dnia [wojny]"), ale też o francusko-brytyjskie porozumienie, że nie podpiszą odrębnego pokoju ani rozejmu. Francuzi odrzucili nawet propozycję Churchilla, aby utworzyć unię francusko-brytyjską. Zob. zwłaszcza J. Baszkiewicz, Historia Francji, Wrocław - Warszawa - Kraków - Gdańsk 1978, s. 681-684.

${ }^{41}$ J. Baszkiewicz, Historia Francji..., s. 686. 
kolaboracji” - napisał francuski historyk ${ }^{42}$, a polski potwierdzi, że „historia reżimu Vichy to dzieje coraz głębszego upadku, coraz obrzydliwszej kolaboracji z hitleryzmem i faszyzacji stosunków wewnętrznych"43. Po zakończeniu wojny światowej musiały, oczywiście, nastąpić zasadnicze przekształcenia ustrojowe we Francji. A w Wietnamie i w Algierii siły zbrojne francuskie ponosiły klęski; z „,desantu sueskiego" (październik - listopad 1956) też trzeba się będzie wycofać na skutek presji USA oraz ZSRR. Tak padła czwarta i narodziła się Piąta Republika.

\section{WOJNY XX WIEKU A PRAWO KARNE}

Niezaprzeczalne jest, iż szczególna rola w kształtowaniu obszaru wolności oraz dla tejże wolności zagrożeń przypada prawu karnemu. Prawo karne w ogóle stanowi szczególnie czuły barometr i wskaźnik charakteru ustroju państwowego i politycznego państwa; prawo karne szczególnie dotkliwie wkracza w naturalne prawa człowieka, w tym w wolność. Z natury swej prawo karne prawa człowieka ogranicza, teoretycznie właśnie dla dobra innych ludzi oraz dla dobra ogółu, dla dobra społeczeństwa, państwa, ewentualnie narodu.

$\mathrm{U}$ progu XX wieku, tuż przed I wojną światową, zasada nullum crimen sine lege wraz z uzupełniającą ją zasadą nulla poena sine lege miały za sobą karierę półtorawiekową, jeśli liczyć symbolicznie od daty (1764) pierwszego wydania wiekopomnej książeczki $O$ przestępstwach $i$ karach markiza z Mediolanu. Wymienione zasady niebezpodstawnie uważane były za fundament praworządności w prawie karnym, podstawę przewidywalności poczynań władzy państwowej w zakresie prawa karnego, fundament bezpieczeństwa prawnego człowieka, które mu się z natury należy. Obie zasady przeto Deklaracja praw człowieka i obywatela ogłaszała (art. 4 i 8) jako ,naturalne, niepozbywalne i święte prawa człowieka”, których zabezpieczenie i przestrzeganie niezbędne miało być dla „szczęścia ogólnego”. Zakaz stanowienia „praw ex post facto” znalazł się w amerykańskiej konstytucji, sformułowany tam dwukrotnie: w odniesieniu do praw federalnych oraz do praw stanowych ${ }^{44}$.

Ta humanitarna reakcja filozofów Wieku Światła i Rozumu na przedoświeceniowy stan niepewności w prawie karnym, na dawniejsze panowanie zasady analogii wiszącej nad człowiekiem niczym miecz Damoklesa, przekształcona została w XIX-wiecznej szkole klasycznej prawa karnego w formalną definicję przestępstwa, zabezpieczającą człowieka i obywatela przed samowolą władzy, trzeciej z władz według Monteskiuszowskiego podziału. Indeterministycznie pojmowa-

\footnotetext{
${ }^{42}$ A. Prost, Zarys historii Francji w XX wieku, thum J. Błońska, Kraków 1997, s. 59.

43 J. Baszkiewicz, Historia Francji..., s. 687.

${ }^{44}$ Art.1, dział 9.3 oraz dział 10.1.
} 
na wina jednostki kształtowała ten oświeceniowy humanitarno-klasyczny model podstaw odpowiedzialności, zaś uzupełniała go Kantowsko-Heglowska odwetowa teoria kary. Liberalno-indywidualistyczne i indeterministyczne koncepcje pierwszych dziesięcioleci epoki postfeudalnej zostały jednak zakwestionowane pod koniec i na przełomie XIX i XX stulecia, najpierw przez skrajnie deterministyczne wizje szkoły antropologicznej, później zaś przez o wiele trwalsze nauki szkoły socjologicznej.

Jeśli zgodzimy się z powszechnym i banalnym poglądem, że prawo karne stanowi szczególnie czuły wskaźnik ustroju państwowego, to dla zagadnienia skutków wojen XX stulecia na prawo karne przychodzi jedynie odpowiedzieć na pytanie pośrednie: które transformacje ustrojowe po wojnach XX wieku powodowały zmiany w prawie karnym i jak głębokie były to zmiany. Tak więc, jak ustroje świata głównych mocarstw zachodniej Europy (Wielka Brytania, Francja) oraz USA pozostały generalnie niezmienione, tak też prawo karne tamże okazało swoją trwałość, nie wkraczając w zwykłą ewolucję. W zasadzie wszystko, co ludzie stworzyli w późnym Oświeceniu i przez cały wiek XIX - nadal jest w uratowanej cywilizacji aktualne. Od około dwustu lat w istocie nie wymyśliliśmy w prawie karnym żadnych wielkich nowości. Ewentualnych nowinek należy przeto szukać w prawie karnym nowych systemów, które wstrząsnęły posadami cywilizacji człowieka - w systemach totalitarnych. Sprawy te mają swoją bogatą literaturę, a w znacznej części są nawet powszechnie znane, toteż przyjdzie jedynie odnotować generalia.

Wielkie problemy XX wieku - jak wszyscy świetnie wiemy - tkwią w tym, że pojawiły się systemy polityczno-prawne nie tylko rażąco naruszające zasady państwa prawnego, lecz wręcz niweczące te zasady; totalitarne ustroje wykazujące nihilizm prawny i pogardę dla człowieka, a tym bardziej dla najbardziej elementarnych praw człowieka. Nie była to zresztą i nie jest cecha tylko Starego Kontynentu. Wraz z upadkiem faszyzmu i komunizmu (nie do końca wszak) problem nie wydaje się być jednak zakończony: przykładem może być wojujący islam.

Pierwszą połowę XX stulecia nazwać można epoką rewolucji. Wszak to rewolucje, głównie te przeprowadzone po I wielkiej wojnie narodów, nadały bieg dziejom ludzkim na następnych lat prawie sto, w wyniku czego cywilizacja naszego globu stanęła na krawędzi zagłady.

„Spustoszone stulecie” (Robert Conquest) to wiek totalitaryzmów. Wszystkie systemy totalitarne były (i są) systemami rewolucyjnymi ${ }^{45} ;$, ,...) żaden historyk nie zdoła nigdy spisać opowieści o naszym własnym stuleciu bez osnucia jej na

${ }^{45}$ C. J. Friedrich, Z. K. Brzezinski, Totalitarian Dictatorship and Autocracy. Cambridge 1956, s. 130; zob. też K. Pomian, Oblicza dwudziestego wieku. Szkice historyczno-polityczne. Lublin 2002, s. 80. 
wątku rewolucji46". Trzeba się zgodzić z cytowanym zdaniem Hannah Arendt, ale też dodać za Janem Baszkiewiczem, że dotyczy to także rewolucji w prawie jako części rewolucji politycznej, która pokonuje dawne instytucje ustrojowe i obala dotychczasowe prawa. Feliks Edmundowicz Dzierżyński odrzucał nawet rewolucyjną praworządność; na posiedzeniu Rady Komisarzy Ludowych miał powiedzieć: „nie myślcie, że szukam rewolucyjnej praworządności, praworządność jest nam dziś zbędna" ${ }^{47}$. Wpisywało się to w Leninowską koncepcję dyktatury proletariatu nieskrępowanej żadnymi, nawet swoimi własnymi, prawami ${ }^{48}$.

Dyktatura proletariatu to m.in. zniesienie podziału władzy. W konsekwencji sądy stanowią taką samą część aparatu państwowego, jak wszystkie inne urzędy. Trzeba ponowić pytanie: po co tutaj sądy? Odpowiedź staje się prosta: sądy, tak jak i inne instytucje przejściowego państwa dyktatury proletariatu, służą walce klasowej, służą do walki. „Stalinizm był wierną kontynuacją leninizmu”, zaś Stalin był „, pewnością, obok Hitlera, człowiekiem, który najbardziej przyczynił się do nadania światu jego obecnej formy" - pisał w połowie lat 70. Leszek Kołakowski $^{49}$.

\section{CRIMINA LAESAE IUSTITIAE ${ }^{50}$}

Więź krajów totalitarnych $\mathrm{z}$ cywilizowanym światem została zerwana w znacznym stopniu na skutek świadomego odrzucenia przez systemy totalitarne consensus iuris, tworzącego społeczeństwa naszych czasów. „W tym miejscu odsłania się zasadnicza odmienność totalitarnej koncepcji prawa od wszystkich pozostałych. Totalitarna polityka nie zastępuje jednego zestawu praw innym, nie stwarza swojego własnego consensus iuris, nie wytwarza za pomocą rewolucji nowych form legalności. Jej lekceważenie dla wszystkich praw, włącznie z tymi, które sama ustanowiła, pozwala sądzić, że wierzy, że może sobie poradzić bez jakiegokolwiek consensus iuris" ${ }^{51}$.

Ideolodzy faszystowscy małą rolę przypisywali prawu - tak Mussolini, jak i Hitler pisali, że nad literą prawa musi wznosić się duch narodowy. Pozytywistyczna koncepcja prawa była krytykowana na rzecz świadomości prawnej, na

${ }^{46}$ H. Arendt, O rewolucji, tłum. M. Godyń, Kraków 1991, s. 259.

${ }^{47}$ Cyt. za: M. Filar, W stużbie utopii: 73 lata radzieckiego prawa karnego, Toruń 1992, s. 11.

48 A. Walicki, Marksizm i skok do królestwa wolności. Dzieje komunistycznej utopii, Warszawa 1996, s. 328-329.

${ }^{49}$ L. Kołakowski, Główne nurty..., s. 794 (cz. III, r. I, pkt 1).

${ }^{50}$ Ten wspaniały, a tragiczny w swojej wymowie termin zapożyczamy z książki Witolda Kuleszy, Crimen laesae iustitiae. Odpowiedzialność karna sędziów i prokuratorów za zbrodnie sądowe według prawa norymberskiego, niemieckiego, austriackiego i polskiego, Łódź 2013.

${ }^{51}$ H. Arendt, Korzenie totalitaryzmu, t. 2, thum. D. Grinberg, Warszawa 2008, s. 232. 
rzecz idei ,żywego prawa”, gdzie sąd miał być zastąpiony sędzią ${ }^{52}$. Ostatecznie $\mathrm{W}$ zgodzie z ideologią - prawo zostało zastąpione przez siłę i terror.

Analogicznie było $\mathrm{w}$ bolszewickim systemie totalitarnym, $\mathrm{z}$ tym że w komunizmie publicznie obłudnie głoszono coś całkiem innego niż było w rzeczywistości. W konsekwencji komuniści, gdy stosowali terror i siłę, na ogół nawet w takich przypadkach „ubierali” swoją działalność w formę wyroku sądowego. Już po wojnie domowej, w 1922 r., Lenin dawał swojemu ministrowi (ludowemu komisarzowi) sprawiedliwości wskazówki: „Sąd nie powinien uchylać się od stosowania terroru; takie zapewnienie byłoby oszukiwaniem siebie lub oszukiwaniem innych - powinien natomiast uzasadnić i zalegalizować go pryncypialnie, jasno, bez fałszu i bez upiększania" ${ }^{53}$.

Komunizm jest najbardziej zakłamanym systemem w dziejach ludzkości. Nigdy i nigdzie nie było takiej rozbieżności między głoszonymi ideami, hasłami, oświadczeniami, prawem na papierze a ,rzeczywistą rzeczywistością”, w przeciwieństwie do „rzeczywistości urojonej” (Franciszek Ancewicz). „Totalne kłamstwo" (Leszek Kołakowski) to jedna z ważnych cech systemu. W to kłamstwo wpisywało się tzw. wymierzanie sprawiedliwości, będące głównie realizacją totalitarnego terroru. Tak było od początku, ale to zwłaszcza „stalinizm, w miarę umacniania się totalitarnego oblicza systemu, coraz bezczelniej poszerzał p r ze paść między fasadą polityczną i rzeczywistością" ${ }^{54}$. Tym różnił się totalitaryzm czerwony od brunatnego, że ten ostatni nie ukrywał swoich celów i wysyłał miliony na śmierć nie potrzebując do tego sądowych wyroków.

Nikt nigdy w dziejach świata nie zbliżył się do wielkości stalinowskiego Wielkiego Terroru, mierzonej liczbą unicestwionych istnień ludzkich. Zarówno ówczesnych obserwatorów, jak i dzisiejszych historyków przerażał i do dzisiaj poraża wymiar kary - z reguły kary najwyższej. Mniej zastanawiano się nad takim fenomenem, że w zasadzie każdy unicestwiany w tym systemie (wszak z góry przewidziany do unicestwienia) miał wyrok. A jeśli w zasadzie każdy powinien być zlikwidowany na mocy wyroku, to trzeba było opracować i uruchomić specjalne formuły pozwalające na wydawanie setek tysięcy, a nawet milionów wyroków. Crimen laesae iustitiae (zbrodnia obrazy sprawiedliwości) w takim systemie musiało być absolutną codziennością, zwykłą częścią tak zwanego wymiaru sprawiedliwości ${ }^{55}$. Realizowano komunistyczny wielki terror w ZSRR przede

${ }^{52}$ A. Wrzyszcz, Okupacyjne sadownictwo niemieckie $w$ Generalnym Gubernatorstwie 1939-1945. Organizacja i funkcjonowanie, Lublin 2008, s. 397-401, passim.

${ }^{53}$ Lenin do Dymitra Kurskiego 7 maja 1922 r. W.I. Lenin: Dzieła wszystkie, t. 45, Warszawa 1989, s. 188.

${ }_{54}$ J. Baszkiewicz, Powszechna historia ustrojów..., s. 356, podkr. w oryginale.

55 A. Lityński, Crimina laesae iustitiae: nazistowskie a komunistyczne. W zwiazku z książka Witolda Kuleszy, Crimen laesae iustitiae. Odpowiedzialność karna sędziów i prokuratorów 
wszystkim w trybie administracyjnym i przez organy pozasądowe, głównie policji politycznej NKWD ${ }^{56}$, przez osławione trojki, dwojki, OSO, chociaż nie tylko. Większość rozstrzelanych oraz populacji łagrów i więzień nigdy sali sądowej nie oglądała. W roku 1937 aż 87\% skazanych było ofiarami trojek i dwojek NKWD ${ }^{57}$. ,[K] to pokładał ostatnią nadzieję w instytucjach prawa musiał doświadczyć tego, że każda z tych instytucji zwracała się przeciwko niemu, stanowiąc część sieci terroru i gnębienia"58.

Zgromadzenie Parlamentarne Rady Europy (rezolucja nr 1096 z 27 czerwca 1996 r.) uznało, iż do likwidacji pozostałości totalitarnego reżimu komunistycznego konieczne jest, aby winni przestępstw ponieśli karę ${ }^{59}$.

\section{WOJNY XX WIEKU A PRAWO PRACY}

Wykształcenie się międzynarodowego prawa pracy jako nowej gałęzi prawa wiąże się z szerszym zagadnieniem, jakim jest wielki rozwój prawa pracy po I wojnie światowej. U progu I wojny światowej, w efekcie powszechnie już głoszonych haseł solidaryzmu społecznego i funkcji społecznej praw podmiotowych, oraz potrzeby podporządkowania interesu indywidualnego względom dobra powszechnego (encyklika Rerum Novarum - 1891), najbardziej rozwinięte państwa były dość zaawansowane w procesie wykształcania się prawa pracy jako odrębnej od prawa cywilnego gałęzi prawa ${ }^{60}$. Przykładem mogły być Niemcy II Rzeszy, gdzie pozycja prawna robotników po ustawach Bismarcka

za zbrodnie sądowe wedtug prawa norymberskiego, niemieckiego, austriackiego i polskiego, Łódź 2013, [art. rec. w:] „Czasopismo Prawno-Historyczne” 2014, z. 2, s. 382.

${ }_{56}$ Народный Комиссариат Внутренних Дел - Narodnyj Komisariat Wnutriennich Dieł [NKWD] - Ludowy Komisariat Spraw Wewnętrznych, czyli ministerstwo spraw wewnętrznych.

57 S. Ciesielski, Wróg jest wszędzie. Stalinowska polityka represyjna w latach 1928-1941. Toruń 2013, s. 222-223.

58 Amerykański Trybunał Wojskowy w wyroku z 4 grudnia 1947 r. w tzw. sprawie prawników; cyt. za Witoldem Kuleszą, Crimen laesae iustitiae..., s. 40.

${ }^{59}$ Zagadnienie odpowiedzialności karnej sprawców zbrodni komunistycznych w Polsce pierwotnie znalazło się w ustawie z 4 kwietnia 1991 r. nowelizującej ustawę o Głównej Komisji Badania Zbrodni Hitlerowskich w Polsce - Instytucie Pamięci Narodowej (Dz.U. nr 45, poz. 195), ale ustawa ta definiowała jedynie zbrodnie stalinowskie (a nie w ogóle komunistyczne) popełnione do 31 grudnia 1956 r. Ważna norma znalazła się w art. 44 Konstytucji RP z 1997 r.: zawiesza się bieg przedawnienia w stosunku do przestępstw popełnionych przez funkcjonariuszy publicznych albo na ich zlecenie, nieściganych z przyczyn politycznych. Warto tu przypomnieć, że Konstytucja w art. 13 zakazuje istnienia partii politycznych odwołujących się do metod i praktyk m.in. komunizmu, zaś art. 256 k.k. z 1997 r. zakazuje propagowania totalitarnego ustroju państwa. A. Lityński, Historia prawa Polski Ludowej..., s. 183-184.

${ }^{60}$ W. Organiściak, Prawo pracy II Rzeczypospolitej. Szkic dla celów dydaktycznych, „Z Dziejów Prawa”, t. 2 (10). Prace Naukowe Uniwersytetu Śląskiego nr 2704, Katowice 2009, s. 233-234. 
uległa zdecydowanej poprawie. Wojna przyniosła jednak radykalizację nastrojów, a przykład rewolucji bolszewickiej i strach przed jej rozprzestrzenieniem się wymuszał nowe ustępstwa wobec klasy robotniczej. Wśród uczestników konferencji w Wersalu wyraźne było przeświadczenie o konieczności ustępstw, czemu dawali publicznie wyraz zarówno T.W. Wilson, jak i G. Clemenceau oraz D. Lloyd George ${ }^{61}$. De facto chodziło o obronę kapitalizmu przed bolszewizmem. Traktat wersalski w części XIII przewidywał utworzenie MOP (ILO), która stała się pierwszą międzynarodową organizacją stojącą na straży określonych praw jednostki. Art. 427 traktatu określał zasady ogólne, na podstawie których miała działać MOP. Znalazły się wśród nich i takie, których realizacja do dziś napotyka na trudności: 1) praca nie może być uważana po prostu za towar lub artykuł handlowy, 2) prawo robotników i pracodawców do zrzeszania się, 3) prawo do godziwego zarobku, 4) maksymalnie 8-godzinny dzień pracy i 48-godzinny tydzień pracy, 5) minimalna 24-godzinna przerwa w pracy raz w tygodniu, 6) zniesienie pracy dzieci, 7) jednolita płaca bez względu na płeć, 8) jednakowa płaca bez względu pochodzenie, 9) utworzenie inspekcji pracy. Do 1939 r. MOP przyjęła 67 konwencji dotyczących różnych aspektów pracy, w tym np. konwencję z 1930 r. dotyczącą pracy przymusowej i obowiązkowej (weszła w życie w 1932 r., ale nie zapobiegła wykorzystaniu pracy więźniów). Niewątpliwie MOP stała się bardzo szybko ważnym elementem międzynarodowego ładu, odgrywając rolę czynnika unowocześniającego krajowe prawo pracy. Przykładem może być Polska, w której w dwudziestoleciu obserwować można stały rozwój ustawodawstwa pracy (np. ustawa z 1937 r. o układach zbiorowych pracy ${ }^{62}$ ). Warto jednak pamiętać, że kodeks zobowiązań z $1933 \mathrm{r}$. (a więc akt $z$ dziedziny prawa cywilnego) normował umowę o pracę. Prawo pracy jako odrębna gałąź prawa, kształtowało się więc stopniowo, czego wyrazem była zapadła w 1938 r. decyzja o wprowadzeniu obowiązkowego nauczania prawa pracy jako odrębnego przedmiotu na polskich wydziałach prawa ${ }^{63}$.

Piękny jest rozwój prawa pracy w krajach cywilizowanych, w systemach liberalnych. Już bylibyśmy gotowi zapomnieć, że wiek XX to „spustoszone stulecie”, spustoszone przez co najmniej dwa systemy ludobójcze, skrajnie zbrodnicze.

„Kto nie pracuje, ten nie je" - było to sztandarowe hasło systemu komunistycznego w ogóle. Początek swój brało z Manifestu komunistycznego. Jak wiadomo, likwidacja własności prywatnej była osią wywodów i wytyczania celów w Manifeście komunistycznym. W konsekwencji wraz z likwidacją własności prywatnej likwidacji miał ulec także kapitalistyczny wolny najem pracy, zaś

\footnotetext{
${ }^{61}$ J. Quigley, Soviet Legal Innovation ..., s. 76-77.

${ }^{62}$ Dz.U. nr 31, poz. 242.

${ }^{63}$ S. Grzybowski, Wspomnienia, Kraków 1999, s. 498.
} 
wprowadzony musiał być ,jednaki przymus pracy dla wszystkich, utworzenie armii przemysłowych, zwłaszcza dla rolnictwa" - stwierdzali twórcy programu komunistycznego $0^{64}$. „Kto nie pracuje, ten nie powinien jeść ${ }^{65}$ - stwierdzał też przyszły wódz rewolucji, Lenin, w napisanej w lecie 1917 r. rozprawce Państwo i rewolucja, a w napisanym przez siebie w marcu 1918 r. projekcie programu partii zawarł kwestię konieczności realizacji powszechnego obowiązku pracy ${ }^{66}$. Powszechny obowiązek pracy wprowadziła Deklaracja praw ludu pracujacego $i$ wyzyskiwanego (25.01.1918) ${ }^{67}$, która następnie weszła w skład (art. 18) pierwszej konstytucji RSFRR (10.07.1918) ${ }^{68}$, co później było kontynuowane w konstytucji stalinowskiej (1936) ${ }^{69}$, mającej wszak długi żywot (do 1977). W komunizmie praca nie miała być motywowana bodźcami materialnymi, lecz samym entuzjazmem. Praca komunistyczna - wywodził Lenin - ,jest to bezpłatna praca na rzecz społeczeństwa, praca wykonywana nie ze względu na określoną powinność, nie w celu otrzymania prawa do określonych produktów (...), wynikająca z nawyku do pracy dla dobra ogółu i oparta na świadomym stosunku (który stał się nawykiem) do niezbędności pracy dla dobra ogółu (...)"’70. Jak wynika z przemyśleń Leszka Kołakowskiego, Lew Dawidowicz Trocki w teoretycznym tekście Terroryzm i komunizm (1921) przedstawił „najogólniejszą teorię państwa dyktatury proletariatu, jaką Trocki u władzy napisał i stanowi najdoskonalszą prezentację systemu, który zwykło się nazywać totalitaryzmem"71. W wywodach Trockiego przymus w państwie proletariatu musi występować na wszelkich poziomach i w rozmaitych formach - w nowym społeczeństwie przymus będzie odgrywał rolę kluczową.

Zasada pracy przymusowej pojawia się jako fundamentalna, bowiem po zlikwidowaniu kapitalistycznego wolnego najmu oraz wolnego rynku do pracy może skłaniać jedynie entuzjazm albo przymus. Zarówno Trocki, jak i Lenin zda-

${ }^{64}$ K. Marks, F. Engels, Manifest komunistyczny, Warszawa 1983, s. 87.

${ }^{65}$ W. Lenin, Państwo i rewolucja, [w:] idem, Dzieła, t. 33, Warszawa 1987, s. 89.

${ }^{66}$ A. Walicki, Marksizm i skok do królestwa wolności. Dzieje komunistycznej utopii, Warszawa 1996, s. 343.

${ }^{67}$ История советской конституции. Сборник документов. 1917-1957, Москва 1957 [Istorija sowietskoj konstitucii. Sbornik dokumentów 1917-1957, Moskwa 1957], s. 44-46; История советской конституичи (в документах) 1917-1956, Москва 1957 [Istorija sowietskoj konstitucii (w dokumentach) 1917-1956, Moskwa 1957], s. 57-59.

${ }^{68}$ Zob. m.in. A. Lityński, Prawo Rosji i ZSRR 1917-1991 czyli historia wszechzwiazkowego komunistycznego prawa (bolszewików). Krótki kurs, Warszawa 2017, s. 56, 61.

69 „Praca w ZSRR jest obowiązkiem i sprawą honoru każdego obywatela zdolnego do pracy, w myśl zasady: »Kto nie pracuje, ten nie je«. W ZSRR realizuje się zasadę socjalizmu: »Od każdego według jego zdolności, każdemu według jego pracy«" (art. 12).

${ }^{70}$ Cyt. za A. Walicki, Marksizm i skok do królestwa wolności..., s. 357; zob. też idem, Zarys myśli rosyjskiej. Od oświecenia do renesansu religijno-filozoficznego, Kraków 2005, s. 687.

${ }^{71}$ L. Kołakowski, Główne nurty..., s 773. 
wali sobie sprawę, że w szerszym wymiarze na motywację emocjonalną chęci do pracy liczyć nie można. Pozostawał przymus: „sama zasada pracy przymusowej jest dla komunisty niepodważalna (...) Jedynym rozwiązaniem trudności ekonomicznych, poprawnym zarówno z punktu widzenia praktyki, jak zasady jest traktować ludność całego kraju jako rezerwuar koniecznej siły roboczej”- wywodził Trocki $^{72}$. Nikołaj Bucharin w tym samym czasie (tj. jeszcze przed wprowadzeniem Nowej Polityki Ekonomicznej - NEP - której Bucharin stał się gorącym zwolennikiem) potwierdzał i rozwijał koncepcję ekonomicznej dyktatury proletariatu, która oznaczała m.in. przymus pracy, a nawet jej militaryzację. Przymus w państwie totalitarnym miał więc być totalny: pełna rekwizycja nadwyżek żywnościowych rolników oraz przymus (a nawet militaryzacja) pracy wszystkich pozostałych $^{73}$. Miało to jednak być państwo komunistyczne, bezklasowe, a więc mimo totalnego przymusu nie było w nim miejsca na wyzysk klasowy, bo wszak proletariat sam siebie wyzyskiwać nie mógł. Według Bucharina wolność wyboru pracy była nie do pogodzenia z gospodarką planową, a gospodarka planowa wymagała precyzyjnego działania, bezwzględnego wykonywania poleceń, szybkich decyzji - jak w wojsku. Tym samym militaryzacja pracy była - według Bucharina - organizacyjnym postępem ${ }^{74}$.

Masowy przymus wymagał masowego terroru. Jedno i drugie stało się codzienną rzeczywistością komunistycznego totalitaryzmu, co ujawniło się i utrwaliło po kilku względnie spokojnych latach NEP-u.

\section{WOJNY XX WIEKU A PROBLEM KODYFIKACJI PRAWA PRYWATNEGO W PAŃSTWACH EUROPY ŚRODKOWO-WSCHODNIEJ ${ }^{75}$}

Zmiany ustrojowe w państwach Europy Środkowo-Wschodniej, będące konsekwencją obu wojen, powodowały powstanie problemów prawnych, wśród których dominuje potrzeba dokonania kodyfikacji narodowych, później narzucona unifikacja wynikająca z politycznej konsolidacji (zwłaszcza po drugiej wojnie światowej), a w końcu zakres rekodyfikacji po upadku bloku wschodniego.

Skutkiem Wielkiej Wojny było uzyskanie politycznej samodzielności narodów funkcjonujących w ramach dotychczasowych mocarstw. Świadomemu budowaniu narodów jako wspólnoty politycznej towarzyszy tworzenie własnego, „,narodowego", prawa. Sprawa kodyfikacji, czy w ogóle jednolitego ustawodawstwa, to

${ }^{72}$ Cyt. za: ibidem, s. 775.

${ }^{73}$ L. Kołakowski, Główne nurty..., s. 813.

${ }^{74}$ A. Walicki, Marksizm i skok do królestwa wolności..., s. 362.

${ }^{75}$ Uwagi dotyczą zwłaszcza państw Europy Środkowo-Wschodniej, które pojawiły się na mapie Europy w wyniku rozpadu monarchii austrowęgierskiej, cesarstwa rosyjskiego i niemieckiego, a po drugiej wojnie światowej pozostawały pod wpływem ZSRR. 
kwestia nie tyle naukowa ${ }^{76}$, co polityczna ${ }^{77}$. Własne (narodowe) ustawodawstwo tworzy podstawę samodzielnego rozwoju nauki, judykatury powodując prawdziwe unarodowienie ${ }^{78}$. To własne prawo miało być wytworem ustawodawcy krajowego w drodze demokratycznej po to, by obywatele mogli się czuć także jego autorami ${ }^{79}$.

Podkreślić należy stałą dążność państw słowiańskich po I wojnie światowej do kodyfikacji prawodawstwa (Komisja Kodyfikacyjna w Polsce, Ministerstwo Unifikacji w Czechosłowacji, Rada Prawnicza w Jugosławii, Komisja Prawa Cywilnego w ramach Rady Państwa na Litwie ${ }^{80}$. Wszystkie te państwa podjęły ogromny trud unifikacji i kodyfikacji prawa prywatnego w krótkim międzywojennym czasie. Wśród nich przoduje Łotwa, która zdołała skodyfikować prawo prywatne przed drugą wojną światową (Kodeks cywilny - 1937) ${ }^{81}$. W międzywojennej Jugosławii - co symptomatyczne - po wydaniu dekretu królewskiego z 3 października 1929 r. intensyfikującego unitaryzm, prace nad unifikacją i kodyfikacją prawa znacznie przyspieszyły. Mimo bardziej skomplikowanej niż w międzywojennej Polsce sytuacji prawnej (szczególnie w obliczu niewypracowania odpowiednich norm kolizyjnych), politycznej i ekonomicznej prace Najwyższej Rady Prawniczej Królestwa Jugosławii przyniosły wymierne rezultaty, a mianowicie pierwszy projekt jugosłowiańskiego kodeksu cywilnego 1934 r., wzorowany w przeważającej mierze na ABGB, ale też ZGB, BGB, kodeksie cywilnym Liechtensteinu i projektowanych wówczas rozwiązaniach węgierskich ${ }^{82}$.

${ }^{76}$ A. Ohanowicz, Unifikacja i reforma prawa cywilnego, „Ruch Prawniczy, Ekonomiczny i Socjologiczny“" 1959 , z. 3, s. 78 .

77 W 1921 r. Naczelnik Państwa Polskiego Józef Piłsudski mówił: „Wadą Komisji Kodyfikacyjnej jest, że jej członkowie, przeważnie profesorowie, dążą do doskonałości i przez to opóźniają przygotowanie jednolitych kodeksów. A przecież z punktu widzenia dobra i spoistości Państwa znacznie jest rzeczą ważniejszą, byśmy jak najrychlej mieli jednolite prawa, niż żeby one były doskonałe. Ulepszać je możecie później. Znaczenia politycznego jak najrychlejszego zunifikowania praw Panowie nie doceniacie i dlatego zbyt dużo mówicie lub piszecie o zabierających czas subtelnościach jurydycznych". Komisja Kodyfikacyjna Rzeczypospolitej Polskiej. Dział ogólny, t. 1, z. 1, Warszawa 1920, s. 21; por. też J. Piłsudski, Pisma zbiorowe, t. 5, red. i wstęp L. Wasilewski, Warszawa 1937, s. 204-205.

78 A. Ohanowicz, Unifikacja..., s. 78.

79 J.M. Smits, Of the vocation of our age against codification: on civil codes in the information society, [w:] J.M. Milo, J.H.A. Lokin, J.M. Smits (eds.), Tradition, Codification and Unification. Comparative - Historical Essays on Developments in Civil Law, Cambridge - Antwerp 2014, s. 242.

${ }^{80}$ Por. B. Boliński, New Codes in The Slavic Countries (Poland, Czechoslovakia, Yougoslavia) by Valdimir Gsovki. Washinton, 1934, „Ruch Prawniczy, Ekonomiczny i Socjologiczny“ 1935, s. 540 .

${ }_{81}$ J. Vebers, Family law in Latvia: From establishment of the independent state of Latvia in 1918 to restoration of independence in 1993, [w:] A. Bainham ed., The International Survey of Family Law, The Hague - Boston - London 1997, s. 207; S. Płaza, Historia Prawa w Polsce na tle porównawczym, cz. III: Okres międzywojenny, Kraków 2001, s. 66.

${ }^{82}$ M. Kresić, Yugoslav private law between the two World Wars, [w:] T. Giaro (Hrsg), Modernisierung durch Transfer zwischen den Weltkriegen, Frankfurt am Main 2007, s. 156-157, 167. 
W Polsce, na Węgrzech i w Czechosłowacji pierwsze w historii kodeksy cywilne powstały i weszły w życie po II wojnie światowej, czyli w czasie, gdy własność prywatna została tam ograniczona do minimum. Tak też w Rosji, gdzie pierwszej kodyfikacji prawa cywilnego dokonano w 1922 r., aczkolwiek w czasie chwilowej „odwilży” (NEP).

Po II wojnie światowej elementem narzuconej politycznej konsolidacji bloku wschodniego było znaczne i wymuszone ujednolicenie zasad poszczególnych gałęzi prawa w ramach „rodziny” prawa socjalistycznego. Należy zwrócić uwagę na fakt, że to niedobrowolne ujednolicenie zostało przeprowadzone w niezwykle szybkim tempie, podobnie jak we wszystkich republikach radzieckich ${ }^{83}$. Odrzucenie w radzieckiej doktrynie i prawie abstrakcyjnego, uniwersalnego pojęcia własności w powiązaniu z publiczną kontrolą nad wszelkimi typami nowo pojętej własności, zwłaszcza własności społecznej, należało przyjąć w całym bloku wschodnim. Można nawet spotkać się z opinią, że w socjalizmie prawo cywilne było prawem prywatnym bez własności prywatnej ${ }^{84}$.

Należy przypomnieć, że w ciągu kilku pierwszych miesięcy po bolszewickim zamachu stanu, do lata 1918 r., praktycznie całe przedrewolucyjne prawo cywilne przestało istnieć ${ }^{85}$. Zupełnie obalono dotychczasowe stosunki własnościowe, czyli prawo rzeczowe (najgruntowniejsze wywłaszczenie w dziejach świata), całkowicie zmieniono stosunki obligacyjne, zlikwidowano prawo spadkowe, stworzono absolutnie nowe, oparte na skrajnie odmiennych zasadach prawo rodzinne. Zauważyć warto, że to wszystko zrealizowano jeszcze zanim dekret $\mathrm{Nr} 3$,o sądzie” wykluczył stosowanie prawa dawnego. W pewnym sensie prawo cywilne uległo zmianie szybciej nawet niż ustawodawstwo karne; fundamentalne zasady dawnego prawa prywatnego zostały zdruzgotane do połowy $1918 \mathrm{r}$. Już w tym czasie powstała baza własności, określanej później jako socjalistyczna, oraz socjalistyczna regulacja jej funkcjonowania: centralizm, akty administracyjne, reglamentacja i rozdzielnictwo. Było to już zupełnie nowe prawo i nie było ono już prawem prywatnym, ius privatum. Przeciwnie - prawo cywilne w systemie radzieckim niezwłocznie stało się prawem publicznym ${ }^{86}$. To absolutna nowość w światowych dziejach prawa.

${ }^{83} \mathrm{~K}$. Lubiński, Tendencje unifikacyjne $w$ rozwoju prawa postepowania cywilnego, [w:] A. Marciniak (red.), Księga pamiątkowa ku czci Profesora Witolda Broniewicza. Symbolae Vitoldo Broniewicz dedicatae, Łódź 1998, s. 230; A. Lityński, Prawo Rosji i ZSRR 1917-1991..., s. 259-227, 245, 301.

${ }^{84}$ L. Vékás, The codification of private law in Hungary..., s. 60.

${ }^{85}$ A. Lityński, Prawo Rosji i ZSRR 1917-1991 ..., s. 232 i n. Podobnie uważa H.C. Reichel, [w:] N. Reich, H.C. Reichel, Einführung in das sozialistische Recht, München 1975, s. 92.

${ }^{86} \mathrm{~Np}$. A. Wyszynski pisał: „U podstaw prawa radzieckiego, a w szczególności u podstaw radzieckiego prawa cywilnego leży nie prawo rzymskie opierające się na prywatnej własności (...), 
Rewolucja proletariacka miała charakter przede wszystkim niszczący - burzyła to, co zastała. Można więc sobie zadawać wstępne pytanie, jak uczynił to jeden z badaczy, czy po rewolucji w ogóle jeszcze jakieś prawo zostało, a w szczególności: czy istniało jeszcze prawo cywilne ${ }^{87}$. „W epoce rewolucji proletariackiej ostatecznie umiera indywidualistyczne prawo cywilne" 88 - twierdził A.G. Gojchbarg.

Ten pierwszy okres rewolucji przeszedł rychło w okres komunizmu wojennego w miesiącach i latach wojny domowej, co trwało do pierwszych miesięcy $1921 \mathrm{r}$. W tych latach dotychczasowe tendencje zastępowania prawa cywilnego prawem administracyjnym jeszcze się umocniły. Zmieniło się to wprawdzie w okresie NEP-u i wówczas pojawiły się kodeksy, w tym także kodeks cywilny. Ale i wówczas ogólny kierunek upublicznienia prawa prywatnego był utrzymywany. Ton i kierunek wskazywał osobiście Lenin; słynna jest jego wypowiedź (z lutego 1922 roku), że ,my niczego prywatnego nie uznajemy, dla nas wszystko (...) jest publicznoprawne" ${ }^{99}$. W przeciwieństwie do klasycznego rozgraniczenia na prawo publiczne i prywatne, komunistyczny system prawny znał jednolitą strukturę prawa: tylko prawo publiczne ${ }^{90}$.

lecz założenia publiczno-prawne”. Zob. A. Wyszynski, Zagadnienia teorii państwa i prawa, Warszawa 1952, s. 139.

${ }^{87}$ N. Reich, Sozialismus und Zivilrecht, Frankfurt am Main 1973, s. 43.

88 А.Г. Гойхбарг, Пролетарская революиия и гражданское право, [w:] А.Г. Гойхбарг, Пролетариат и право. (Сборник статей). Издание Народного Комиссариата Юстиции [A. G. Gojchbarg, Proletarskaja rewolucija i grażdanskoje prawo, [w:] Proletariat i prawo. (Sbornik statiej). Izdanije Narodnogo Komissariata Justicii], [b.m.] 1919, s. 16, zob. także s. 6.

89 „Przygotowuje się nowe ustawodawstwo cywilne. Ludowy Komisariat Sprawiedliwości »płynie z prądem«; widzę to. A ma obowiązek walczyć przeciw prądowi. Niech nie przejmuje starego, burżuazyjnego pojęcia prawa cywilnego (ściślej, nie dać się nabierać tępym i burżuazyjnym starym prawnikom, którzy je przejmują), lecz tworzy nowe. Niech nie ulega Ludowemu Komisariatowi Spraw Zagranicznych, który »z obowiązku« stoi na stanowisku »przystosowania się do Europy«, lecz walczy z tym stanowiskiem, kształtuje nowe prawo cywilne, nowy stosunek do "prywatnych« umów itp. My niczego »prywatnego« nie uznajemy, dla nas wszystko, co dotyczy gospodarki, jest publicznoprawne, a nie prywatne. Zezwalamy na kapitalizm tylko państwowy, państwo zaś to my, jak powiedziano wyżej. Stąd - rozszerzyć zakres ingerencji państwa w stosunki »prywatnoprawne«; rozszerzyć jego prawo do uchylania "prywatnych« umów; stosować nie corpus iuris romani do »stosunków cywilnoprawnych«, lecz naszą rewolucyjną świadomość prawną; systematycznie, uparcie, wytrwale ukazywać w wielu pokazowych procesach, jak to należy czynić rozsądnie i energicznie; w drodze partyjnej stawiać pod pręgierzem i przepędzać tych członków trybunałów rewolucyjnych i sędziów ludowych, którzy się tego nie uczą i nie chcą zrozumieć". W. Lenin, Dzieła wszystkie, t. 44 , s. 379-380 (podkr. w oryginale).

${ }^{90}$ H.C. Reichel, [w:] N. Reich, H.C. Reichel, Einführung in das sozialistische Recht..., s. 85. 
Oddzielenie prawa cywilnego od prawa prywatnego jest być może najważniejszą nowością, jaką modernistyczna cywilistyka radziecka wprowadziła do powszechnej teorii prawa ${ }^{91}$.

Po upadku bloku wschodniego w wyniku zimnej wojny należało niezwłocznie zdemontować instytucje socjalistyczne. Początkowo sprowadzało się to do wielokrotnego nowelizowania kodeksów cywilnych w zakresie wybranych instytucji w poszczególnych ich częściach, względnie do nowelizowania nieskodyfikowanego prawa w państwach byłej Jugosławii. Należy jednak podkreślić, że wymuszona implementacja instytucji socjalistycznych po drugiej wojnie światowej nie spowodowała zaniku wzorców zachodnich, co z kolei dało szansę państwom Europy Środkowo-Wschodniej na dokonanie transformacji w dość szybkim tempie ${ }^{92}$.

Faktem jest, że różne instytucje pochodzenia zachodniego lub wschodniego zawsze były mieszane ze sobą w zależności od dominującej politycznej scenerii regionu, wytworzonej w efekcie wojen XX wieku. Zagadnienie zmieniających się wzorców regulacji cywilnoprawnych i zderzenia dawnej tradycji z nowymi instytucjami po drugiej wojnie światowej oraz próba uwzględnienia współcześnie najnowszych zdobyczy cywilistyki skutkuje obecnie zjawiskiem, które można nazwać hybrydyzacją prawa w państwach Europy Środkowo-Wschodniej. Niezależnie od tego podkreśla się narodowość efektu w postaci kodeksu cywilnego, jak np. w Czechach (2012), mimo silnych wpływów germańskich, a następnie komunistycznych ${ }^{93}$.

Mimo usunięcia zasadniczych socjalistycznych instytucji z kodeksów cywilnych powstałych w państwach satelickich ZSRR (tzw. demokracjach ludowych) niemal wszystkie te państwa z mniejszym lub większym oporem uznały ostatecznie za konieczne dokonanie nowej kodyfikacji cywilnej. Decyzję o nowej kodyfikacji podjęli nawet Serbowie, wyjątkowo przywiązani do swojego kodeksu z 1844 r., którym wyprzedzili wiele państw bardziej rozwiniętych. W zasadzie dopiero wiek XXI przyniósł wymierne efekty w postaci własnych „narodowych” kodyfikacji cywilnych, w szczególności na Węgrzech (2013), w Czechach (2012), na Litwie (2000), w Estonii (2002) i na Ukrainie (2003) ${ }^{94}$, a w pozostałych państwach, w tym w Polsce, proces ten trwa nadal.

${ }^{91}$ N. Reich, Sozialismus und Zivilrecht..., s. 337.

${ }^{92}$ K. Kelemen, B. Fekete, How Should the Legal System of Eastern Europe be Classified Today? [w:] A. Badó, D.W. Belling, J. Bóka, P. Mezei (eds.), International Conference for the 10th Anniversary of the Institute of Comparative Law, Potsdam 2014, online: https://ssrn.com/abstract=2614944, s. 213.

${ }_{93}$ P. Dostalík, O. Horák, Zmiany w czeskim prawie prywatnym, „Forum Prawnicze” 2014, s. $16-25$.

${ }^{94}$ Por. H.L. MacQueen, Private Law's Revolutionaries: Authors, Codifiers and Merchants? [w:] S. Worthington, A. Robertson, G. Virgo (eds.), Revolution and Evolution in Provate Law, Oxford, UK - Portland, Oregon 2018, s. 42. 
Wiek XX to zatem nie tylko wiek ustrojowych transformacji w Europie Środkowo-Wschodniej, lecz także wiek kodyfikacji i zmian ustrojowych, które wymuszały nowe ujęcie regulacji kodeksowych.

Reasumując: to, na co wojny XX wieku nie miały wpływu, to sama idea kodyfikacji, która pozostaje generalnie niezmienna od XVIII w. - nadal żyje i ma się dobrze, mimo wojen i rewolucji. Kodyfikacja jawi się więc jako historyczny fenomen, który wciąż determinuje prawniczą świadomość w naszej kulturze prawnej.

\section{KILKA UWAG O WPŁYWIE WOJEN NA POLSKIE PRAWO PRYWATNE}

Niniejszy tekst wskazywał już pewne czynniki, które w wyniku wojen miały wpływ na rozwój prawa, w tym coraz szybciej publicyzującego się prawa prywatnego. Jednym z nich była emancypacja kobiet, które w czasie I wojny zostały w wielu krajach włączone w znacznie większym niż dotychczas stopniu w życie społeczeństw. Kobiety stały się faktycznie pełnoprawnym uczestnikiem życia społecznego, co musiało skutkować między innymi zmianą przepisów prawa cywilnego, które dotychczas przewidywały ograniczenia w pozycji prawnej kobiet. Przykładowo, w Polsce konstytucja marcowa opierała się na zasadzie równouprawnienia płci, stąd dość szybko Sejm Ustawodawczy uchwalił ustawę z 1 lipca 1921 r. ${ }^{95}$, która zmieniała przepisy kodeksu cywilnego Królestwa Polskiego oraz prawa małżeńskiego z $1836 \mathrm{r}$. między innymi w zakresie opieki, zarządu majątkiem małżeńskim oraz wzajemnych praw i obowiązków małżonków. Zakres terytorialny ustawy ograniczał się do byłego Królestwa Polskiego, gdyż tam przypadków przepisów zawierających nierówności między małżonkami było najwięcej. Prawo polskie stopniowo znosiło także inne nierówności niż wynikające z różnicy płci. $\mathrm{Na}$ terytorium ziem wschodnich obowiązywało rozporządzenie Prezydenta RP z 14 października 1927 r. o uchyleniu odrębności stanowych ${ }^{96}$. Kompleksowy charakter miała natomiast krótka ustawa z 13 marca 1931 r. o wygaśnięciu mocy prawnej przepisów wyjątkowych, związanych z pochodzeniem, narodowością, językiem, rasą lub religią obywateli Rzeczypospolitej ${ }^{97}$. Problem z tą ustawą był jednak taki, że nie wskazywała ona konkretnych uchylonych przepisów, zawierając jedynie normę generalną. Powodowało to trudności interpretacyjne, a stan ten można było zmienić jedynie przez wydanie nowych przepisów jednolitych dla całego obszaru państwa, uchylających stare.

${ }_{95}$ Ustawa z 1 lipca 1921 r. w przedmiocie zmiany niektórych przepisów prawa cywilnego, dotyczących praw kobiet (Dz.U. nr 64, poz. 397).

${ }^{96}$ Dz.U. poz. 92, nr 824.

${ }^{97}$ Dz.U. nr 31, poz. 214. 
Bezpośredni związek ze skutkami wojny miało uchwalenie ustawy z 27 stycznia 1922 r. „W przedmiocie zmiany i uzupełnienia niektórych przepisów obowiązującego w b. Królestwie Polskiem kodeksu cywilnego z 1825 oraz ustawy postępowania cywilnego, dotyczących nieobecnych i zaginionych"98. Ustawa ta nadała nowe brzmienie kodeksowym przepisom o nieobecnych. Dział III (art. 46-55) o uznaniu osób zaginionych za zmarłe zawierał nowoczesne rozwiązania, które - w naszej opinii - zostały częściowo wykorzystane w unifikacyjnym dekrecie Prawo osobowe z 1945 r. Nie sposób tu pominąć przepisów znowelizowanego działu IV o skutkach uznania osoby zaginionej za zmarłą oraz nowelizacji przepisów rosyjskiej ustawy postępowania cywilnego (art. 2 ustawy z 1922 r.). Również te rozwiązania stały na wysokim poziomie i obowiązywały na terenie całego byłego zaboru rosyjskiego. Zgodnie bowiem z rozporządzeniami Rady Ministrów z 1922 r. ${ }^{99}$ i 1924 r. ${ }^{100}$ przepisy ustawy z 1922 r. rozciągnięto na obszar byłego zaboru rosyjskiego, poza byłym Królestwem Polskim. W ten sposób większość terytorium polskiego została przyporządkowana nowoczesnemu prawu o uznaniu za zmarłego, powstałemu wyraźnie w związku ze skutkami wojny. Wspominamy o tym również dlatego, że przepisy o uznaniu za zmarłego, które obowiązują dzisiaj jako część kodeksu cywilnego, wykazują podobieństwo do wcześniejszych polskich rozwiązań przyjmowanych od 1922 r. Rzecz ciekawa, powstawały one poza Komisją Kodyfikacyjną II RP.

Druga wojna światowa problem uznania za zmarłego zdecydowanie bardziej wyostrzyła. Pisał o tym jeden z twórców unifikacji prawa cywilnego, A. Wolter:

\begin{abstract}
już w czasie trwania, a zwłaszcza po zakończeniu pierwszej wojny światowej, przepisy dotyczące uznania za zmarłego zyskały niepomiernie na aktualności w stosunku do czasów dawniejszych; toteż większość państw była zmuszona poddać odnośne postanowienia swoich ustawodawstw gruntownej rewizji. Aczkolwiek dzieli nas od tego czasu zaledwie ćwierć wieku, ten problem stał się znów palącym (...). W Polsce ponadto powstała dalsza kwestia, a mianowicie unifikacji przepisów, dotyczących uznania za zmarłego, gdyż dziedzina ta dotychczas stała pod rządem ustaw dzielnicowych ${ }^{101}$.
\end{abstract}

Warto odnotować fakt, iż w czasie II wojny światowej rząd RP na uchodźstwie pracował nad ustawą o zaginionych i zmarłych. Powstały nawet trzy projekty ustawy, a jeden $\mathrm{z}$ nich został stworzony w okupowanym kraju ${ }^{102}$. Ostatecznie

98 Dz.U. nr 11, poz. 87.

${ }^{99}$ Dz.U. nr 43, poz. 360

${ }^{100}$ Dz.U. nr 32, poz. 326.

101 A. Wolter, Uznanie za zmartego. Rozdziat trzeci dziatu pierwszego prawa osobowego, „Demokratyczny Przegląd Prawniczy" 1945, nr 1, s. 25.

102 A. Kozioł, Prace nad unifikacja prawa cywilnego w Polsce w latach 1945-1946, maszynopis rozprawy doktorskiej powstałej na Wydziale Prawa i Administracji Uniwersytetu Śląskiego pod kierunkiem A. Lityńskiego, Katowice 2006, s. 23-28. 
dekret z 29 sierpnia 1945 r. prawo osobowe ${ }^{103}$ wykorzystywał rozwiązania wcześniejszych projektów. Zbadana dotychczas tylko wyrywkowo praktyka stosowania zunifikowanych przepisów wskazuje, że powojenny polski ustawodawca należycie unormował to tragiczne wojenne spustoszenie ${ }^{104}$, między innymi przez skrócenie terminów wymaganych do uznania osoby za zmarłą lub zaginioną.

Jak wiadomo, Komisja Kodyfikacyjna w II RP nie zakończyła prac nad unifikacją prawa cywilnego przed wybuchem II wojny. Poza Komisją powstała natomiast ustawa z dnia 13 lipca 1939 r. o ułatwieniu przysposobienia małoletnich ${ }^{105}$, która zdecydowanie uprościła procedurę adopcyjną wobec małoletnich. Jej ratio legis sprowadzało się do zlikwidowania masowego zjawiska sieroctwa w Polsce ${ }^{106}$. W warunkach II wojny ustawa odegrała bardzo ważną rolę: ułatwiała ona uratowanie (niestety, nie wiemy w jak dużej skali ${ }^{107}$ ) sierot po zamordowanych przez okupanta niemieckiego rodzicach. Zjawisko uproszczonego sposobu i trybu przysposobienia w czasie II wojny znane jest na ziemiach polskich w odniesieniu do dzieci żydowskich: jesienią 1942 r. w łódzkim getcie rozpoczęto akcję adopcyjną. Rodziny, które zdecydowały się przyjąć do swego domu dziecko, otrzymywały dodatkowe przydziały żywności. Podstawą adopcji były specjalne dekrety adopcyjne, wydawane przez Komisję Opieki nad Osieroconymi Dziećmi ${ }^{108}$. Niestety, los tych dzieci był ostatecznie równie tragiczny, jak los ich opiekunów.

W pracach nad unifikacją prawa cywilnego w zakresie przepisów o przysposobieniu odwołano się do konieczności ułatwienia adopcji w związku ze skutkami wojny. Dekret z 22 stycznia 1946 r. prawo rodzinne ${ }^{109}$ w art. 76-84 regulował całkowicie na nowo tę instytucję, a przepisy opierały się na zawartym w tezach założeniu o konieczności ułatwienia korzystania z tej instytucji po II wojnie światowej ${ }^{110}$. W świetle przepisów przysposobienie miało charakter minus plena ${ }^{111}$.

${ }_{103}$ Dz.U. nr 40, poz. 223.

104 Zob. S. Przewoźnik, Uznanie za zmarlego w świetle akt Sądu Grodzkiego w Krakowie w latach 1946-1950, maszynopis rozprawy doktorskiej powstałej w Krakowskiej Akademii im. A. Frycza Modrzewskiego pod kierunkiem I. Lewandowskiej-Malec, Kraków 2015, ss. 246.

${ }_{105}$ Dz.U. nr 63, poz. 416.

${ }^{106}$ P. Fiedorczyk, Kilka uwag o genezie ustawy z dnia 13 lipca 1939 r. o ułatwieniu przysposobienia małoletnich, „Studia Iuridica Lublinensia” 2016, nr 25, nr 3, s. 301-312.

107 A. Stelmachowski, Przysposobienie w polskim prawie rodzinnym, Warszawa 1957, s. 81.

108 E. Wiatr, Wstęp, [w:] R. Lipszyc, Dziennik z getta łódzkiego, Kraków - Budapeszt 2017, s. xvi.

${ }_{109}$ Dz.U. nr 5, poz. 21, sprostowanie: Dz.U. z 1946 r. nr 16, poz. 113.

110 „Tragiczne skutki ostatniej wojny spowodowały konieczność jak najdalej idącego ułatwienia przysposobienia celem umożliwienia stworzenia rodzin zastępczych dla sierot" - stwierdzało uzasadnienie do tezy VIII w ostatecznej redakcji tego dokumentu (Archiwum Akt Nowych, zespół: Ministerstwo Sprawiedliwości, sygn. 4306, k. 481).

${ }^{111}$ W trakcie konsultacji projektu sędzia Sądu Apelacyjnego w Katowicach dr S. Gronowski proponował, by rozszerzyć skutki prawne adopcji, słusznie uzasadniając, iż pełna adopcja lepiej 
Nasze dotychczasowe rozważania pomijały najbardziej bodaj interesującą społeczeństwo kwestię z zakresu prawa rodzinnego: prawo rozwodowe. W pracach nad unifikacją osobowego prawa małżeńskiego w 1945 r. problem ten objawił się $\mathrm{w}$ postaci zerwania $\mathrm{z}$ kościelnym postulatem nierozerwalności małżeństwa i zastąpieniem go zasadą trwałości, która oznaczała jednak dopuszczenie możliwości rozwodu w razie zaistnienia określonych przesłanek. Rząd w akcji propagandowej posłużył się argumentem skutków wojny dla rodzin jako uzasadnieniem dopuszczalności rozwodu. Kampania propagandowa w oficjalnej prasie odwoływała się do niezrozumiałego dla części społeczeństwa hasła „świeckości prawa małżeńskiego". Argumentem za rozwodami miała być krytyka dogmatów katolickich o nierozerwalności małżeństwa. „Nie ma świecie świętości takiego Sakramentu, który miałby prawo przykuć żołnierza spod Lenino czy Tobruku do kochanki niemieckiego gestapowca. Albo nawet kobietę, która przeniosła cały ciężar lat wojny i okupacji do człowieka wracającego do domu z chorobą weneryczną zamiast ran i odznaczeń" - pisał w sierpniu 1945 r. jeden z dzienników lokalnych ${ }^{112}$. Ostatecznie rozwód został w dekrecie z 25 września 1945 r. uregulowany według konstrukcji K. Lutostańskiego sprzed wojny (1929 r.), ale dekret przepisy wprowadzające prawo małżeńskie ${ }^{113}$ zawierał dwa „wojenne” przepisy rozwodowe, stanowiące wyjątki od zasady trwałości małżeństwa. Art. XII tego dekretu pozwalał na rozwiązanie małżeństwa przez rozwód, jeżeli jeden z małżonków wpisał się w czasie okupacji na niemiecką listę narodową. Była to jedyna, w pełni wystarczająca przesłanka rozwodu, nieistotne tutaj było nawet dobro małoletnich dzieci ${ }^{14}$. Ratio legis tego przepisu opierało się więc na tezie szkodliwości społecznej utrzymywania związków małżeńskich z osobami narodowości niemieckiej $^{115}$. Znacznie ważniejszy wyjątek został sformułowany w art. XIII przepisów wprowadzających. Zgodnie z jego treścią można było na zgodny wniosek stron, bez orzekania o winie, rozwiązać przez rozwód każde małżeństwo mające więcej niż trzyletni staż małżeński. Prawo to miało charakter wyjątkowy, gdyż obowiązywało tylko przez trzy lata po wejściu w życie dekretu, tj. do 31 grudnia 1948 r. Samo jednak jego istnienie uznać należy za wielki eksperyment społeczny, gdyż

odpowiada potrzebom okresu powojennego. Zob. AAN MS 4306, k. 552. Warto zwrócić uwagę, że adoptio minus plena została bardzo szybko poddana krytyce praktyków, którzy wskazywali na jej sprzeczne z interesem społecznym skutki. Zob. A. Dokowska, Przysposobienie a życie, „Demokratyczny Przegląd Prawniczy" 1947, nr 7, s. 33-35.

112 Cyt. za: A. Lachowicz, Laicyzacyjna rola reformy prawa matżeńskiego i urzędów stanu cywilnego w woj. białostockim w latach 1945-1948, „Studia Podlaskie” 2001, t. XI, s. 219.

113 Dz.U. nr 48, poz. 271.

114 J. Witecki, Prawo matżeńskie z komentarzem, Warszawa 1946, s. 75.

115 Szerzej na ten temat: M. Tkaczuk, [w:] D. Janicka (red.), Judiciary and Society between Privacy and Publicity. 8th Conference on Legal History in the Baltic Sea Area, 3rd-6th September 2015, Toruń, Toruń 2016, s. 164-173. 
pozwalało ono na rozwiązanie wcześniej zawartych małżeństw praktycznie bez żadnych ograniczeń. Ustawodawca wyjaśniał, że celem przepisu jest likwidacja faktycznie nieistniejących małżeństw i uporządkowanie stanu cywilnego społeczeństwa, a utrzymywanie fikcji jest sprzeczne ze społecznymi celami rodziny. Był to najbardziej radykalny przepis o rozwodzie w polskim ustawodawstwie do dziś, a problem jego stosowania oczekuje na zbadanie.

Zasygnalizowane powyżej niektóre wątki wpływu wojen XX w. na prawo prywatne stanowią oczywiście tylko fragment wielkiego zagadnienia. Pojawia się tu w szczególności prawo majątkowe, które pozostawiamy poza zakresem rozważań. Wymieńmy niektóre z zagadnień: odszkodowania wojenne, reparacje, uzasadnianie przekształceń własnościowych koniecznością likwidacji skutków wojny (np. tzw. dekret Bieruta dotyczący gruntów warszawskich; mienie obywateli polskich pozostawione za Bugiem).

\section{ZIMNA WOJNA: ETAPY, FORMY, ZAKOŃCZENIE, SKUTKI USTROJOWE I PRAWNE. CZY TO KONIEC KONFRONTACJI ZACHODU I WSCHODU?}

Nie będziemy próbowali konstruować żadnej oryginalnej definicji pojęcia zimnej wojny, rozumiejąc ją - jak to powszechnie się czyni - jako konfrontację dwóch systemów: komunistycznego oraz świata zachodniego, a głównie liderów tych odmiennych światów: ZSRR oraz USA. Konfrontacja ta miała aspekty tak bardzo wielopłaszczyznowe, że możliwe będzie jedynie ich skatalogowanie z uwypukleniem co najwyżej niektórych.

Na wstępie powstaje natomiast pytanie o zakres chronologiczny okresu zimnej wojny. Zazwyczaj odnosi się go do okresu po II wojnie światowej, widząc jego koniec najpóźniej z upadkiem lidera komunizmu - ZSRR. Co do terminu a quo, to dla jego ustalenia nie da się uniknąć wkroczenia w rozmaite płaszczyzny zimnej wojny. W pamięci ludzkiej z pewnością pierwsze skojarzenie to konfrontacja militarna, wyścig zbrojeń, który wszak groził wybuchem wojny o niespotykanej i trudno wyobrażalnej sile zniszczenia. Punktem wyjścia konfliktu zimnowojennego były jednak różnice ideowe. Ojcami komunizmu byli przecież twórcy Manifestu komunistycznego oraz przywódca rewolucji Lenin i jego następca Stalin, zaś ojcami zachodniego systemu demokratyczno-liberalnego byli ojcowie amerykańskiej Deklaracji Niepodległości oraz francuskiej Deklaracji Praw Człowieka i Obywatela. Marksizm-leninizm-stalinizm jako swoje credo miał rozszerzenie w świecie zasięgu rewolucji proletariackiej i zwłaszcza w pierwszych latach po czerwonym październiku 1917 r. głosił rychłe obalenie burżuazyjnych rządów i stworzenie wszędzie republik radzieckich. $Z$ tym zamiarem szedł na 
zachód w 1920 r., „po trupie Polski”. To w celu szerzenia rewolucji właśnie wtedy utworzono Komintern (1919-1943), zaś wydarzenia (1919) w Budapeszcie, w Niemczech, a zwłaszcza w Bawarii, wydawały się potwierdzać te rachuby; tylko niepokorna Polska stanęła na drodze pochodowi rewolucji - tej „lokomotywy dziejów". Po rzeczywistym końcu I wojny światowej, tzn. po traktacie ryskim podpisanym w 1921 roku, Komintern zdecydował, że proletariat świata ma całą energię skierować na wspieranie radzieckiej Rosji (wkrótce ZSRR) i w istocie utożsamiał interesy rosyjskie $\mathrm{z}$ rewolucyjnymi interesami proletariatu zobowiązanego do działania na rzecz obalenia rządów. Kiedy kapitalizm wszedł w okres kryzysu (1929 i następne), zaś ZSRR wszedł w okres gospodarki planowej, dla Stalina i Kominternu śmierć sytemu zachodniego stała się oczywista i bliska, a więc należało się do niej przyczynić. Rację ma Robert Conquest, gdy pisze, że „,z komunistycznego punktu widzenia nigdy nie wchodziła w grę trwała zgoda pomiędzy ZSRR a światem »kapitalistycznym«"116. Taką próbą sił dwóch systemów totalitarnych (Niemcy i Włochy versus ZSRR/Międzynarodówka Komunistyczna) była między innymi wojna domowa w Hiszpanii (1936-1939).

Przypomnienie tych znanych faktów ma wskazać, że zimna wojna dwóch systemów zaczęła się wraz z narodzinami systemu komunistycznego, zaczęła się $\mathrm{w}$ istocie w 1917 r., co zresztą zbiega się w czasie z narodzinami (powolne to narodziny) potęg komunistycznej Rosji oraz światowego pierwszeństwa gospodarczego i militarnego USA. Dojście do władzy nazistów w Niemczech oraz japońska ekspansja w Azji i podpisanie Paktu Antykominternowskiego (1936; Niemcy, Japonia, Włochy) wyciszyło zimną wojnę, ale na krótko, bo do chwili niespodziewanego dla zachodniego świata podpisania paktu Ribbentrop-Mołotow. Ten zaś pakt ujawnił ukrytą motywację Moskwy, motywację bynajmniej nie ideologiczną, lecz czysto imperialistyczną.

Pierwszym, chyba najważniejszym skutkiem paktu Ribbentrop-Mołotow było to, że świat stanął w obliczu zagłady dotychczasowej cywilizacji. Absolutnie nie do przyjęcia jest twierdzenie niektórych historyków zachodnich, że sierpniowy sojusz hitlerowsko-stalinowski miał na celu tylko zyskanie przez Rosję na czasie. To był prawdziwy sojusz totalitarnych imperiów o ludobójczych zamiarach, gotowych zniszczyć cywilizację człowieka, ukształtowaną co najmniej od czasów oświecenia.

Innym skutkiem była ekspansja terytorialna czerwonej Rosji. Imperium Rosyjskie wszak I wojnę światową przegrało, ale na skutek inercji Zachodu i wczesnego wycofania się USA ze spraw europejskich Rosja zyskała wiele z ziem nierosyjskich, do czerwonej Rosji je siłą przyłączając. Jednak niektóre narody uratowały się od okupacji rosyjskiej tworząc swoje suwerenne państwa: Polska,

116 R. Conquest, Uwagi o spustoszonym stuleciu, thum. T. Bieroń, Poznań 2002, s. 211. 
kraje bałtyckie, Finlandia. W sierpniu 1939 r. czerwone imperium rozpoczęło co najmniej odzyskiwanie terenów dawnej Rosji, które od niej odpadły przed $1921 \mathrm{r}$. Imperializm komunistyczny nie miał zabarwienia ideologicznego. Powszechnie znany dalszy przebieg wydarzeń wojennych skutkował nie tylko odzyskaniem przez czerwone imperium prawie wszystkich (z wyjątkiem Finlandii) ziem imperium carów, lecz także uzyskaniem zdobyczy terytorialnych znacznie większych, o jakich Rosja carska marzyć nie mogła: całej Europy Środkowo-Wschodniej i częściowo centralnej aż po Łabę. Wszędzie tam Moskwa zaprowadziła rychło swoje porządki; wyjątkiem była tu Jugosławia, gdzie panował „komunistyczny sojusznik amerykański" ${ }^{117}$.

Tu może jedynie powstać pytanie, czy dla wspomnianej części wschodniej Europy wynikiem II wojny światowej była zmiana ustroju, czy też była to sowiecka okupacja ${ }^{118}$ maskowana przez geniusza obłudy - Stalina - formalnym zachowaniem zewnętrznych oznak niezawisłości. W naszym przekonaniu miało miejsce to drugie: sowiecka okupacja z zachowaniem niektórych elementów autonomii. Europa została podzielona żelazną kurtyną, jak to określił Churchill.

Zaczęła się druga odsłona zimnej wojny. Wówczas też (w listopadzie 1947) określenie ,zimna wojna” weszło na trwałe do słownika polityki, a to wraz z książką bardzo znanego dziennikarza - komentatora politycznego - Waltera Lippmana, The Cold War. W pełni podzielić trzeba też ówczesny wywód Lippmana, że Stalin nie jest spadkobiercą Marksa, lecz Piotra Wielkiego, i kontynuuje imperialistyczne dążenia carów ${ }^{119}$. Wreszcie, w 30 lat po bolszewickim zdobyciu władzy, ktoś to wyraźnie światu powiedział.

Tyle o początku zimnej wojny, który widzimy już w 1917 r., a po II wojnie nową jej odsłonę i dynamikę. Wojna jeszcze się nie skończyła, a na konferencji jałtańskiej (w lutym 1945) Stalin zażądał rewizji konwencji z Montreux (1936) ${ }^{120}$, w której mocarstwa przyznały Turcji prawo obrony cieśnin czarnomorskich. W czerwcu 1945 r. Stalin zażądał od Turcji zwrotu okręgów Kars i Ardahan, które wszak ZSRR przyznał Turcji w 1921 r., wspólnie dokonując rozbioru Armenii (zob. wyżej pkt 2). Miesiąc później Stalin i Mołotow oświadczyli, że obrona cieśnin czarnomorskich powinna być wspólną sprawą ZSRR i Turcji. W grudniu

117 T. Jakovina, Američki komunistički saveznik. Hrvati, Titova Jugoslavija i Sjedinjene Države 1945-1955, Zagreb 2003.

118 Zob. A. Ajnenekiel (red.), Wojna domowa czy nowa okupacja? Polska po roku 1944, Warszawa 2001.

119 D.C. Engerman, Ideologia a geneza zimnej wojny, [w:] M. Leffler, O.A. Westad (red.), Historia zimnej wojny, t. I: Geneza, thum. M. Grzywa, Oświęcim 2017, s. 53.

120 Konwencja z 20.07.1936, anulująca wcześniejsze postanowienia konferencji w Lozannie (1923), której sygnatariuszem stał się także ZSRR, pozwala na swobodny przepływ nietureckich statków oraz w ograniczonym zakresie okrętów wojennych. 
1945 r. dwieście czołgów radzieckich przekroczyło granicę z Iranem i część z nich zajęła pozycje wzdłuż granicy irańsko-tureckiej ${ }^{121}$. Związek Radziecki zmierzał, podobnie jak w Europie Środkowo-Wschodniej, do przekształcenia Turcji w państwo satelickie,. Łatwo zauważyć, że i na tym obszarze ZSRR kontynuował kierunek ekspansji terytorialnej jeszcze Imperium Rosyjskiego i wobec chwiejnej postawy Turcji w latach II wojny światowej na Kremlu mogła zrodzić się nadzieja na kontynuację rozbioru Turcji, jak to się działo po I wojnie. Na tym by się zapewne nie skończyło. Podsekretarz stanu USA Dean Acheson przedstawił (15.08.1946) prezydentowi Trumanowi raport, w którym pisał, że „głównym celem Związku Sowieckiego jest przejęcie kontroli nad Turcją. Jeśli Sowietom uda się opanować Turcję, powstrzymanie ich przed podporządkowaniem sobie Grecji oraz całego Bliskiego i Środkowego Wschodu będzie zadaniem niezwykle trudnym, o ile w ogóle wykonalnym"122. Dalej raport wskazywał na zagrożenie dla Indii i Chin. Zauważmy, że po oddaniu sowietom m.in. Bułgarii i Rumunii oraz po zainstalowaniu się komunistów w Jugosławii i rewolcie komunistów greckich łączność Turcji z Zachodem została przecięta. Truman wysłał w rejon cieśnin potężny zespół operacyjny US Navy. Sowieci się zatrzymali.

Przyszły wybitny dyplomata George F. Kennan, wówczas przeciętnego szczebla urzędnik ambasady amerykańskiej w Moskwie, w słynnym „długim telegramie" (8 tysięcy słów, luty 1946) sformułował doktrynę powstrzymywania Związku Radzieckiego, co przyjął na stałe prezydent Truman, ale doktryna Trumana nie odnosiła się do tych terytoriów, które już znalazły się w sowieckiej strefie wpływów. Na sowiecką blokadę Berlina świat zachodni odpowiedział mostem powietrznym, ale nie wjazdem czołgów do radzieckiej strefy okupacyjnej. Zupełnie inaczej było w Grecji (1946-1949), która znalazła się w zachodniej strefie wpływów. Z kolei na powołanie NATO (1949) strona komunistyczna odpowiedziała powołaniem Paktu Warszawskiego (1955) dopiero po sześciu latach, ale też w silnie scentralizowanym i w pełni zależnym od Moskwy systemie nie było konieczności pośpiechu. Na powołanie RFN (23.05.1949) strona komunistyczna natychmiast zareagowała powołaniem (07.10.1949) NRD. Później (lato 1961) budowa muru berlińskiego zaakcentowała tylko podział świata na strefy wpływów, od których drugiej stronie wara. Przez 16 godzin stały (27.10.1961) na Checkpoint Charlie z lufami skierowanymi przeciw sobie czołgi radzieckie i amerykańskie, ale jednak wycofały się. W 1956 r. na Węgrzech

121 J. Chace, Dzień, w którym zaczęta się zimna wojna, [w:] Zimna wojna, thum. M. Urbański, Warszawa 2009, s. 19 i n.

${ }^{122}$ Cyt. za J. Chace, Dzień, w którym zaczęta się zimna wojna..., s. 27; zob. też M.P. Leffler, Narodziny amerykańskiej wielkiej strategii 1945-1952, [w:] M. Leffler, O.A. Westad (red.), Historia zimnej wojny, t. I: Geneza, tłum. M. Grzywa, Oświęcim 2017, s. 85. 
i w 1968 r. w Czechosłowacji owa nienaruszalność stref wpływów drastycznie się ujawniła przed światem.

Sformułowana we wrześniu 1968 r. tzw. doktryna Breżniewa oficjalnie stwierdzała ograniczoną suwerenność państw tzw. demokracji ludowej. Wprawdzie każde państwo mogło kroczyć „własną drogą do socjalizmu”, ale to nie mogło „szkodzić socjalizmowi w ich kraju ani też fundamentalnym interesom pozostałych krajów socjalistycznych lub walczącemu o socjalizm światowemu ruchowi robotniczemu". Gdyby tak się zdarzyło, to pozostałe kraje socjalistyczne pod wodzą Związku Radzieckiego mają ,internacjonalistyczny obowiązek” - tak jak w Czechosłowacji - „przeciwstawić się zdecydowanie antysocjalistycznym siłom". Z doktryny Breżniewa zrezygnowano dopiero w 1989 r. ${ }^{123}$

Zimna wojna powędrowała wkrótce do Azji, do Ameryki Łacińskiej oraz do krajów Trzeciego Świata. Na rubieżach zimnej wojny pojawił się proces dekolonizacji (Indie, Pakistan - 1947 i inne kraje), a najważniejszym wydarzeniem tej wczesnej fazy było komunistyczne zwycięstwo w Chinach i powstanie (01.10.1949) Chińskiej Republiki Ludowej. Później pojawią się lokalne wojny, często wojny domowe, w Iranie, Egipcie, Indonezji, Libanie, Gwatemali, powstanie Castro na Kubie (1956-1959), interwencja w Zatoce Świń na Kubie; specjalnego znaczenia nabrały wojny koreańska oraz wietnamska, a w końcu radziecka agresja w Afganistanie ${ }^{124}$ (grudzień 1979 - luty 1989) oraz wojna w Zatoce Perskiej. Lokalne wojny, które zdarzały się i wcześniej, w wyniku zaangażowania rywalizujących mocarstw stały się wielokrotnie intensywniejsze i dla ludności tych krajów drastycznie dolegliwe. Niektórzy nazywają takie konfrontacje wojnami zastępczymi, których istota polega na starciu głównych mocarstw nie bezpośrednio, lecz na terenie państwa trzeciego i siłami osobowymi najczęściej też obcymi. Zimna wojna obfitowała w takie wojny zastępcze.

Nie da się zapomnieć kryzysu kubańskiego (jesień 1962) w związku z radziecką próbą zainstalowania tam rakiet średniego ${ }^{125}$ zasięgu, kiedy to rzeczywiście świat stanął na krawędzi globalnej wojny nuklearnej. Rzadziej się pamięta, że wówczas obie strony uczyniły krok do tyłu, bowiem za demontaż radzieckich instalacji na Kubie USA zapłaciły trwałym wycofaniem swoich rakiet z Turcji. Ten przypadek wyraźnie pokazał, że zimna wojna w Trzecim Świecie może stać się zapalnikiem wojny światowej o nasileniu w historii niespotykanym.

123 Zob. m.in. A. Lityński, Prawo Rosji i ZSRR 1917-1991..., s. 404.

${ }^{124}$ Warto zauważyć, że ZSRR kontynuował tu kierunek ekspansji terytorialnej jeszcze Imperium Rosyjsksiego z przełomu XIX i XX wieku, tzw. The Great Game. Zob. wyżej pkt 1 niniejszego tekstu.

${ }^{125}$ O postępie w dziedzinie rakiet balistycznych i technologii zbrojeniowej zob. interesującą syntezę J.F. Guilmartin jr, Międzykontynentalne rakiety balistyczne a zimna wojna: technologia u steru, [w:] Zimna wojna, tłum. M. Urbański, Warszawa 2009, s. 440 i in. 
„Przez czterdzieści z górą lat żyliśmy w nieustannym strachu przed wojną. Zegar nuklearnego sądu ostatecznego wydawał się na trwałe ustawiony w pozycji za minutę północ - godzinę duchów dla świata"126.

Szczególnym obszarem konfrontacji w całym powojennym okresie zimnej wojny (i nadal) stał się Bliski Wschód. Po rewolucji 1905 r. i późniejszych represjach (pogromach) w Rosji bardzo wzrósł napływ żydowskich osadników z Imperium Rosyjskiego do Palestyny. Zasadnicze wydarzenia sięgają I wojny światowej i rozbioru Imperium Osmańskiego, kiedy to zwłaszcza Brytyjczycy szukając wsparcia przeciwko Turcji (Imperium Osmańskiemu) zawierali lokalne sojusze z Arabami i obiecywali im niepodległość, ale brytyjska polityka pełna była sprzeczności i wykluczających się obietnic ${ }^{127}$. Ostatecznie też Arabowie opowiadali się w zasadzie za państwami centralnymi, zaś Żydzi postawili na Ententę i podjęli działania aktywne wojskowe (legion żydowski) oraz dyplomatyczne. Te ostatnie owocowały tzw. deklaracją Balfoura, która była jedną z wielu odnoszących się do Bliskiego Wschodu po wojnie i pewnie - jak inne - poszłaby szybko w zapomnienie, gdyby nie aktywne działania syjonistów na świecie. Brytyjczycy zaczęli najpóźniej w połowie 1917 r. postrzegać ruch syjonistyczny jako sojusznika, bez zrywania stosunków z Arabami. Po ostateczny złamaniu wojsk osmańskich to Brytyjczycy weszli (09.12.1917) do Jerozolimy i opanowali całą Palestynę. Po długich jeszcze zawirowaniach dyplomatycznych Wielka Brytania otrzymała mandat Ligi Narodów na Palestynę 29 września 1923 r. Wojny arabsko-żydowskie przybrały na sile. Druga wojna światowa przyniosła Holokaust, jednocześnie wysuwając problem państwa żydowskiego na salony polityczne i czołówki gazet zyskując poparcie dla idei odrębnego państwa żydowskiego. Pod koniec II wojny światowej żydowskie organizacje militarne organizowały serie zamachów terrorystycznych na placówki i instytucje brytyjskie oraz ośrodki zamieszkałe przez ludność arabską. Brytyjczycy nie byli w stanie i nie chcieli dłużej zarządzać terytorium mandatowym. Zgromadzenie Ogólne ONZ (29.09.1947) uchwaliło plan podziału Palestyny ${ }^{128}$ oraz zakończenie mandatu brytyjskiego 15 maja 1948 r. 14 maja 1948 r. Żydowska Rada Ludowa ogłosiła deklarację niepodległości państwa Izrael. Jak wiadomo, dalsze dzieje stosunków żydowsko-arabskich obfitują w wojny, w których pośrednio ${ }^{129}$ lub nawet bezpośrednio uczestniczyły mocarstwa światowe.

126 J. Prados, Panika wojenna roku 1983, [w:] Zimna wojna, thum. M. Urbański, Warszawa 2009, s. $440 \mathrm{i}$ in.

127 K. Schulze, Konflikt arabsko-izraelski, thum. B. Hlebowicz, Warszawa 2010, s. 21, passim.

128 Powierzchnia państwa żydowskiego miała wynosić $14257 \mathrm{~km}^{2} \mathrm{z}$ ludnością 935 tys., w tym 42\% to ludność arabska; Palestyńczykom przyznano 11664 km² z ludnością 814 tys., w tym ludność żydowska to $1 \%$. Jerozolima miała uzyskać status ponadpaństwowy (corpus separatum).

${ }^{129}$ M.in. Kreml poniósł klęskę na Bliskim Wschodzie w wyniku wojny sześciodniowej arabsko-izraelskiej (czerwiec 1967). Wcześniej włożono duży wysiłek w odbudowę egipskich sił zbroj- 
Teraz kilka uwag o narzędziach zimnej wojny, które widzimy jako odmienne przed i po II wojnie światowej. Instrumenty wykorzystywane do prowadzenia zimnej wojny to oczywiście przede wszystkim zbrojenia. Związek Radziecki we wczesnym okresie po II wojnie przeznaczał na ten cel nawet do jednej trzeciej swoich możliwości gospodarczych ${ }^{130}$. Obok tego ogromne sumy pochłaniały służby wywiadów i kontrwywiadów oraz akcje propagandowe. Te ostatnie na szeroką skalę prowadziła tylko strona komunistyczna, zaś zachodniej udało się tylko uruchomienie Radia Wolna Europa i Radia Swoboda. Sowieci zaś byli bez porównania hojniejsi; na przykład tylko na kampanię przeciwko bombie neutronowej przeznaczyli około stu milionów dolarów ${ }^{131}$. Mimo dużych sukcesów w wojnie psychologicznej (np. wystrzelenie pierwszego satelity-sputnika - październik 1957; światowe kampanie „walki o pokój” i in.) i politycznej (m.in. układ SALT I korzystny dla ZSRR), strona komunistyczna poniosła i $\mathrm{w}$ tej materii porażkę w latach 80 ., za prezydentury Ronalda Reagana. W latach 80 . „piekielny pociąg wyścigu zbrojeń jądrowych nabierał niesamowitego przyspieszenia" ${ }^{132}$. Jak powszechnie wiadomo, klęska ZSRR w zimnej wojnie wynikała z niemożliwości udźwignięcia ciężaru zmilitaryzowania gospodarki, do czego przyczynił się zwłaszcza Reaganowski program tzw. gwiezdnych wojen oraz Reaganowskie doprowadzenie do drastycznego spadku cen ropy naftowej ${ }^{133}$. W Moskwie umacniało się przekonanie, że Reagan chce wygrać wojnę nuklearną z ZSRR. Napięcie w Moskwie doszło do szczytu w czasie listopadowych (1983) ćwiczeń NATO. KGB doszedł do wniosku, że wojska amerykańskie zostały postawione w stan gotowości i może nawet zaczęło się już odliczanie przed atakiem atomowym. „Ludzkość przestała być nieśmiertelna”"134.

Przegrana przez ZSRR zimna wojna przyniosła wolność licznym krajom i narodom zniewolonym. Niektóre wróciły do niepodległości (nadbałtyckie), inne po raz pierwszy (jeśli nie liczyć krótkotrwałych prób wcześniejszych) ją uzyskały (Zakaukazie, także faktycznie Ukraina i Białoruś). Niepodległość to oczywiście nowe systemy ustrojowe, za czym szło budowanie własnych systemów prawa cywilnego i karnego.

nych. KGB miał ogromne osiągnięcia w penetrowaniu Egiptu, mówiono nawet o „Egipskiej Republice Radzieckiej”. Po nagłej śmierci proradzieckiego prezydenta Egiptu G. Nassera (1970) - jego następca A. Sadat formalnie podpisał układ o przyjaźni z ZSRR, ale aresztował frakcję promoskiewską i agentów KGB, a wkrótce (1972) radzieckim „doradcom” nakazał opuścić kraj. A. Lityński, Prawo Rosji i ZSRR 1917-1991..., s. 403-404.

${ }^{130}$ D.C. Engerman, Ideologia a geneza zimnej wojny..., s. 55.

131 R. Conquest, Uwagi o spustoszonym stuleciu..., s. 236.

132 M. Gorbaczow, Sam ze wspomnieniami, tłum. O. Morańska, Warszawa 2014, s. 293-294.

133 Zob. M. Gorbaczow, Sam ze wspomnieniami..., s. 311; obszernie i interesująco na ten temat zob. P. Schweizer, Wojna Reagana, thum. P. Amsterdamski, Warszawa 2004, s. 263-266, 284.

134 M. Gorbaczow, Sam ze wspomnieniami..., s. 293. 
„Żaden wyczyn komunizmu nie zadziwił świata tak bardzo, jak sposób jego zejścia ze sceny dziejów” 135 . „Przecież dotychczas wszystkim zakrętom historycznym w kraju towarzyszył rozlew krwi" ${ }^{136}$. Ale czy to koniec zimnej wojny pomiędzy światem zachodniej kultury a Rosją?

Ostatnią wojną w XX-wiecznej Europie była wojna w byłej Jugosławii. W XXI stuleciu już mamy za sobą rosyjską agresję na Gruzję (w sierpniu 2008), rosyjską agresję i inkorporację Krymu (w marcu 2014) oraz wschodniej części Donbasu wraz ze zbrodniami na ludności cywilnej, z czego najgłośniejsze było zestrzelenie samolotu pasażerskiego z osobami cywilnymi na pokładzie, i ostatnio (w listopadzie 2018) wydarzenia w Cieśninie Kerczeńskiej (tzw. incydent na Morzu Azowskim). Dotychczas agresor stale jest ten sam - Rosja; jest zwycięski i pozostaje bezkarny.

\section{$20^{\mathrm{TH}}$ CENTURY WARS AND THEIR CONSEQUENCES FOR DIFFERENT FORMS OF GOVERNMENT AND FOR LAW}

\section{Summary}

The Russo-Japanese War, fought between 1904 and 1905, started a period of wars in the $20^{\text {th }}$ century. As a result of the First World War, as many as four empires collapsed and, at the same time, revolutions took place in at least three of them; namely in Russia, German Reich, and the Ottoman Empire while the Hapsburg Empire was affected by the revolution only to a certain extent. As a matter of fact, the First World War did not finish on the $11^{\text {th }}$ of November 1918. Russia - both "white" and "red" - and Turkey resumed their military conflict after the $11^{\text {th }}$ of November 1918. The war ended in March 1921.

The so-called Treaty of Versailles which brought an end to World War I constituted an explosive growth of international public law. Its main aim was to preserve international peace and safety; however, it was unsuccessful in this respect. Moreover, the idea of self-determination theoretically gained great importance. New states appeared on the map in Central and Eastern Europe - specifically between Germany and Russia - which did not exist before 1914. And so the end of World War I had to result in the expansion of the reach of democracy. Furthermore, after the Second World War, the principle of international responsibility for war crimes, crimes against humanity and genocide (Latin genocidium) was partially realized. Nevertheless, it did not pertain to the USSR, which was one of the victors.

The first half of the $20^{\text {th }}$ century can be called an era of revolution. The revolutions created the most criminal and genocidal totalitarian systems in the history of mankind. The bond between the totalitarian countries and the civilized world was broken, among others, in regard to law. For example, after the First World War, there was enormous

135 M. Malia, Sowiecka tragedia. Historia komunistycznego imperium rosyjskiego 1917-1991, Warszawa 1998, s. 444; zob. też A Lityński, Prawo Rosji i ZSRR 1917-1991..., s. 148.

136 M. Gorbaczow, Sam ze wspomnieniami..., s. 322. 
development in labour law which veered towards positive changes for workers. On the other hand, it was common in the totalitarian systems to use slave labour and it was done on a large scale.

The end of both world wars in the $20^{\text {th }}$ century resulted in political changes and, consequently, also in changes in the area of criminal law and civil law. The emergence of new states after World War I also led to the process of law codification. Furthermore, this process also took place after the Second War when the states of the so-called Soviet Bloc created their own codes based on Soviet models. As a result of both wars, numerous problems arose which were connected with, for example, war reparations, compensation, territorial changes, justification of ownership transformation, family law as well as marriage law institutions, and others.

The Cold War - a confrontation between the communist system and the liberal western system - essentially began together with the beginning of the communist system already in 1917. It only acquired a new dynamic after the Second World War. The Cold War soon spread throughout Asia, Latin America and the Third World countries. The USSR lost the Cold War and in consequence it brought freedom to numerous enslaved countries and nations. Naturally, independence meant new forms of government which were followed by the creation of civil and criminal law systems.

\section{GUERRES DU XX ${ }^{\mathrm{E}}$ SIECLE ET LEURS CONSEQUENCES POUR LES SYSTEMES ETATIQUE ET JURIDIQUE}

\section{Résumé}

La guerre russo-japonaise de 1904-1905 marque le début de la période des guerres du $\mathrm{XX}^{\mathrm{e}}$ siècle: quatre empires se sont effondrés, et sur les territoires des trois parmi eux les révolutions ont éclatées (la Russie, l'Empire allemand, l'Empire ottoman et une révolution a affectée 1'Empire des Habsbourg seulement dans une certaine mesure). En fait, la Première Guerre mondiale ne s'est pas terminée le 11 novembre 1918, la Russie - aussi « blanche » que « rouge » - et la Turquie ont repris la guerre après le 11 novembre 1918; la fin de la guerre a eu lieu en mars 1921.

Le soi-disant système de Versailles qui met fin à la Première Guerre mondiale constitue une explosion du développement du droit international public. Il visait principalement à maintenir la paix et la sécurité internationales, et cela n'est jamais arrivé. Aussi, l'idée d'autodétermination des peuples a théoriquement pris une grande importance. Sur la carte de l'Europe centrale et orientale - entre l'Allemagne et la Russie - apparaissaient des États nationaux qui n'existaient pas avant 1914. La fin de la première grande guerre a du entraîner un élargissement de l'espace démocratique. Par contre, après la Seconde Guerre mondiale, le principe de la responsabilité internationale pour les crimes de guerre, contre l'humanité et le génocide (génocidium) a été partiellement appliquée. Cependant, cela ne concernait pas l'URSS qui se trouvait parmi les gagnants.

La première moitié du $\mathrm{XX}^{\mathrm{e}}$ siècle peut être appelée la première ère de révolution. Les révolutions ont créé les systèmes les plus criminels de l'histoire de l'humanité, totalitaires et génocidaires. Le lien des pays totalitaires avec le monde civilisé, y compris dans le domaine du droit, a été interrompu. Après la Première Guerre mondiale, par exemple, le droit 
du travail a connu un grand développement favorable pour les employés, mais dans les systèmes totalitaires, le travail d'esclave obligé était utilisé largement et à grande échelle.

La fin des deux guerres du $\mathrm{XX}^{\mathrm{e}}$ siècle a entraîné des changements systémiques, et par conséquent, le droit pénal et civil ont été modifiés. La création de nouveaux États, après la Première Guerre mondiale, a entraîné le processus de codification du droit. Ce processus a également eu lieu après la Seconde Guerre mondiale, alors que les pays du soi-disant bloc soviétique ont créé des codes basés sur des modèles soviétiques. À la suite des deux guerres, de nombreux problèmes sont apparus, notamment les problèmes liés avec les dommages de guerre, réparations, modification des frontières, justification des transformations de propriété, institutions de droit familial et matrimonial, etc.

La guerre froide - une confrontation du système communiste et de l'Occident libéral - a en fait commencé avec la naissance du système communiste, dès 1917. Après la Seconde Guerre mondiale, elle n'a fait que gagner une nouvelle dynamique. La guerre froide a rapidement atteint l'Asie, l'Amérique latine et les pays du tiers monde. La guerre froide, perdue par l'URSS, a apporté la liberté à de nombreux pays et nations réduits en esclavage. L'indépendance a bien sûr aidé former de nouveaux systèmes politiques, et ceux-ci ont donné l'impulsion à l'instauration de leurs propres systèmes de droit civil et pénal. 